Article

\title{
Ore Assimilation and Secondary Phases by Sintering of Rich and High-Gangue Iron Ores
}

\author{
Roland Mežibrický ${ }^{1, *}$, Mária Fröhlichová ${ }^{1}$, Róbert Findorák ${ }^{1}$ and Valerie Sue Goettgens ${ }^{2}$ \\ 1 Institute of Metallurgy, Technical University of Košice, Letná 9, 04200 Košice, Slovakia; \\ maria.frohlichova@tuke.sk (M.F.); robert.findorak@tuke.sk (R.F.) \\ 2 Institute of Mineralogy and Petrography, University of Innsbruck, Innrain, 52, 6020 Innsbruck, Austria; \\ valerie.goettgens@student.uibk.ac.at \\ * Correspondence: mezibricky@azet.sk; Tel.: +421-55-602-3165
}

Received: 6 February 2019; Accepted: 19 February 2019; Published: 22 February 2019

check for updates

\begin{abstract}
During the iron ore sintering process, two types of particles are present in the sinter bed: (1) fines, which are actively taking part in melting and the formation of secondary phases, and (2) coarse ores, which are partially interacting with the surrounding melt. The quality of the final sinter is particularly determined by the secondary phases and their bonding ability. Due to chemical differences between the fines and coarse particles, knowing the overall chemical composition of the sintering blend is not sufficient to estimate the final sinter microstructure. In this study, different ore types were used to prepare iron-rich, high-alumina, and high-silica blends, which were sintered in a laboratory sinter pot to investigate the behavior of fine as well as coarse particles. As a result, very different sinter matrices formed depending on the useful basicity in each sinter. The density, mineral nature, and the gangue of the ore affected coarse ore assimilation.
\end{abstract}

Keywords: chemical composition; iron ore; mineralogy; sintering; size distribution

\section{Introduction}

The ferrous raw materials for the modern blast furnace ironmaking route are natural or pre-treated iron ores, which are mostly supplied in a fine-grained form. Regarding the grain size, powdery ore particles are processed by pelletizing, while ore fines with a wider size distribution up to $10 \mathrm{~mm}$ are better for use in the sinter plants. Utilization of almost all fine-grained waste materials from the ironmaking route is advantageous for sintering since this reduces the processing price. Furthermore, changing the composition (e.g., the basicity- $\mathrm{CaO} / \mathrm{SiO}_{2}$ ratio), according to the current blast furnace charge requirements, makes the sintering process the most important fine iron ore coarsening method [1].

For typical sintering, ore concentrates, and iron ores without any previous enrichment are used. The quality of the latter, known as the sintering ore, is highly dependent on the quality of the mined deposit. Moreover, the gangue content of iron ores is constantly increasing. Therefore, sinter ores with higher silica and alumina content are being considered for use or are already being processed [2-5].

Currently, the regional iron ore market conditions lead to the use of high-gangue ores. The sintering of high- $\mathrm{SiO}_{2}$ iron ores is typical for the region of Central Europe and Eastern Europe, where iron ores from Ukraine and Russia are processed. The silica content in the final sinter reaches $7-10 \mathrm{wt} \%$ $\mathrm{SiO}_{2}$ [6]. Another region with high-gangue sintering is India, where the domestic high-alumina iron ore is consumed. As a result, sinters in Indian blast furnaces contain 3-5 wt $\% \mathrm{Al}_{2} \mathrm{O}_{3}$ [7]. Another ore type of increasing importance, which is typical for some ironmaking facilities in China, comprises magnetite ores containing vanadium, titanium, and chromium admixtures $[8,9]$. Lastly, the sinter quality is highly dependent on and determined by the properties of the phases, which the sinter consists of. 
The mineralogy of iron ore sinters is quite complex. The main phases are the iron oxides magnetite and hematite in an unreacted primary form or as secondary phases formed by reactions or precipitation from the melt. As typical secondary compounds in lime-fluxed iron ore sinters, calcium ferrites and calcium silicates form the sinter matrix. Recent works dealing with the mineralogy of iron ore sinters mostly focus on the complex calcium ferrite phase [10-12]. During the ferrite formation process, silica and alumina enter the structure, which results in crystallization of aluminosilicoferrites of calcium (often referred to as SFCA, short for silico-ferrite of calcium and aluminum). In the currently produced high-basicity sinters, two homologues of SFCA are present: $\mathrm{Ca}_{2}(\mathrm{Ca}, \mathrm{Fe}, \mathrm{Al})_{6}\left(\mathrm{Fe}, \mathrm{Si}, \mathrm{Al}_{6} \mathrm{O}_{20}\right.$ and $\mathrm{Ca}_{3}(\mathrm{Ca}, \mathrm{Fe})^{2+}(\mathrm{Fe}, \mathrm{Al})^{3+}{ }_{16} \mathrm{O}_{28}$, denoted as SFCA and SFCA-I, respectively [13]. These phases are considered the most important for the sinter properties. Furthermore, other calcium ferrite types or homologues related to SFCA and SFCA-I have been investigated: $\mathrm{Ca}_{2 .} \mathrm{Fe}_{10.5} \mathrm{Si}_{0.6} \mathrm{O}_{20}$ [14], $\mathrm{Ca}_{2}(\mathrm{Ca}, \mathrm{Fe}, \mathrm{Mg}, \mathrm{Al})_{6}(\mathrm{Fe}, \mathrm{Si}, \mathrm{Al})_{6} \mathrm{O}_{20}$ [15], $\mathrm{Ca}_{5.1} \mathrm{Al}_{9.3} \mathrm{Fe}^{3+}{ }_{18.7} \mathrm{Fe}^{2+}{ }_{0.9} \mathrm{O}_{48}$ [16], $\mathrm{Ca}_{3} \mathrm{MgAl}_{6} \mathrm{Fe}_{10} \mathrm{O}_{28}$ [17], or $\mathrm{Ca}_{2.38} \mathrm{Mg}_{2.09} \mathrm{Fe}^{3+}{ }_{10.61} \mathrm{Fe}^{2+}{ }_{1.59} \mathrm{Al}_{9.33} \mathrm{O}_{36}$ [18].

The conditions for the formation of the secondary phases are already partially determined before the sintering process. One of the important factors is the size distribution of the particles in the sinter blend. The ore fines are mixed together with fluxes as well as fuel, and are subsequently granulated with the addition of a little water, which forms granules with different sizes. During this process, coarser ore particles act as nuclei, on which the remnants of adhering fines are balled. The heat released by the burning fuel melts the finest particles and the melt then partially penetrates the nuclei surface. As a result, secondary phases formed by chemical reactions during sintering and are crystallized from the melt bind the unreacted coarse nuclei into the sintered product [19].

There is a history of efforts to understand the roles of ore fines and coarse particles in assimilation and matrix formation in the scientific literature [20-24]. However, most of it is based on experiments conducted in laboratory-scale electric furnaces. Thus, the real sintering conditions are only approximately simulated. In this study, real sintering materials are used for sintering in a pot with internal heating via fuel mixed into the sintering mixture. The advantages of pot sintering compared to electric furnaces are as follows: (i) there is no need to simulate the atmosphere, which changes during the process, and (ii) natural ores with original size distributions of the particles can be used. On the other hand, the amount of sintering mixtures used in this study is small enough to enable a more detailed material-oriented research rather than a technical report.

This work focuses on describing the differences between the chemical compositions of fine and coarse ore particles, which act as the adhering layer and nuclei of sinter granules, respectively. For this purpose, three different scenarios are compared: low-gangue, high- $\mathrm{Al}_{2} \mathrm{O}_{3}$, and high-SiO mixtures. At the same time, the influences of adhering layers and nuclei particles are investigated during the formation of new phases and phase assemblages when sintering.

\section{Materials and Methods}

\subsection{Raw Materials}

For the experiments, three iron ores were chosen including one Brazilian (Carajás) and two Ukrainian ores (Sukha Balka and Zaporozhskiy). The overall chemical composition of the ores is shown in Table 1. The ore from Carajás is a high-grade iron ore with only low gangue content, which is mainly silica and alumina ( 1.40 and $0.67 \mathrm{wt} \%$, respectively). It is noteworthy that the contents of $\mathrm{TiO}_{2}$ and manganese ( 0.18 and $0.54 \mathrm{wt} \%$, respectively) are a little higher compared with the usual values for iron ores.

The Sukha Balka ore is a high-SiO 2 iron ore in which the silica content exceeds $10 \mathrm{wt} \%$. This high gangue value makes the Ukrainian ore extraordinary in comparison with other iron ores commonly used for sintering purposes. However, almost all iron ores classified as sintering ores exploited and exported from Ukraine have very high silica levels and the content of 8-10 wt \% is typical. Besides silica, there are minor gangue constituents. The composition of the Zaporozhskiy ore is very similar even though the silica content is a little lower. 
Alumina powder (99 wt \% $\mathrm{Al}_{2} \mathrm{O}_{3}$, particle size: $100 \%,-0.063 \mathrm{~mm}$ ) was used as an additional reagent to achieve high-alumina content that could not be obtained with the natural ores alone. All mixtures were fluxed with ordinary limestone and fueled with coke breeze (11 wt \% ash, 0.8 wt \% humidity).

Table 1. Chemical composition of the raw materials, dry wt \%.

\begin{tabular}{cccccc}
\hline Component & Carajás & Sukha Balka & Zaporozhskiy & Limestone & Coke Ash \\
\hline $\mathrm{Fe}_{\text {total }}$ & 65.15 & 61.94 & 62.41 & $\mathrm{NA}$ & 19.02 \\
$\mathrm{FeO}$ & 0.26 & 0.30 & 1.15 & $\mathrm{NA}$ & 0.00 \\
$\mathrm{Fe}_{2} \mathrm{O}_{3}$ & 92.86 & 88.22 & 87.96 & 0.00 & 27.20 \\
$\mathrm{CaO}$ & 0.06 & 0.10 & 0.69 & 46.37 & 6.80 \\
$\mathrm{SiO}_{2}$ & 1.40 & 10.28 & 8.54 & 2.51 & 34.70 \\
$\mathrm{Al}_{2} \mathrm{O}_{3}$ & 0.67 & 0.77 & 1.09 & 1.30 & 21.10 \\
$\mathrm{MgO}_{\mathrm{TiO}}$ & 0.11 & 0.10 & 0.32 & 4.28 & 2.80 \\
$\mathrm{Na}_{2} \mathrm{O}$ & 0.18 & 0.01 & 0.01 & $\mathrm{NA}$ & 0.00 \\
$\mathrm{~K}_{2} \mathrm{O}$ & 0.03 & 0.11 & 0.07 & $\mathrm{NA}$ & 1.10 \\
$\mathrm{Mn}$ & 0.03 & 0.05 & 0.05 & NA & 1.60 \\
$\mathrm{P}$ & 0.54 & 0.02 & 0.05 & NA & 0.12 \\
$\mathrm{~S}$ & 0.02 & 0.02 & 0.05 & NA & 0.36 \\
$\mathrm{LOI}$ & 0.01 & 0.01 & 0.02 & NA & NA \\
\hline
\end{tabular}

* Loss on ignition, incl. surface humidity and structurally bonded water. NA: not analyzed.

In addition to the overall analysis, the chemical composition of ore materials as a function of the size fraction was studied as well (Niton XRF Analyzer, Thermo Fisher Scientific, Waltham, MA, USA). Table 2 summarizes the contents of 1 size fractions of each ore and their chemical compositions. In all three cases, a similar trend is observed in which the finer the ore particles are, the richer in iron they are.

The most iron-rich ore from Carajás shows a gradual decrease in total iron content from $\sim 68 \mathrm{wt} \%$ in the finest to $\sim 63 \mathrm{wt} \%$ in the coarsest fraction. At the same time, the contents of the components $\mathrm{CaO}, \mathrm{SiO}_{2}$, and $\mathrm{MgO}$ increase. The $\mathrm{Al}_{2} \mathrm{O}_{3}$ content is elevated within the finest and coarsest particles (about $1 \mathrm{wt} \%$ ), and the minimum is reached within the $+2-3.15 \mathrm{~mm}$ fraction $(0.53 \mathrm{wt} \%$ ).

In the Sukha Balka ore, significant differences appear between the fine and coarse particles. The $\mathrm{Fe}_{\text {total }}$ content gradually decreases by 17 percentage points from $\sim 65 \mathrm{wt} \%$ in the finest to $48 \mathrm{wt} \%$ in the coarsest due to the silica content, which reaches more than $17 \mathrm{wt} \%$ in the fraction $+8 \mathrm{~mm}$. The finest fraction $-0.063 \mathrm{~mm}$ contains less than $5 \mathrm{wt} \%$ of $\mathrm{SiO}_{2}$. Because of the almost evenly distributed fraction ratios, the overall silica content of the Sukha Balka ore practically corresponds to the average value. A remarkable feature is the peak content of $\mathrm{Al}_{2} \mathrm{O}_{3}$ in fractions $+0.125-0.5 \mathrm{~mm}$ at the level of $\sim 1.7 \mathrm{wt} \%$.

Similar to the Sukha Balka ore, in the sample from Zaporozhskiy, the iron content decreases significantly with coarsening of the ore particles. However, the decrease is not so pronounced, from $\sim 64$ to $\sim 59 \mathrm{wt} \%$ of $\mathrm{Fe}_{\text {total }}$. Furthermore, the spread of the $\mathrm{SiO}_{2}$ content is less distinct. The particles $-0.5 \mathrm{~mm}$ contain more $\mathrm{Al}_{2} \mathrm{O}_{3}$ and $\mathrm{CaO}, \sim 1.5$ and $\sim 0.8 \mathrm{wt} \%$, respectively.

The distribution of the chemical components within the mineral phases in the studied ores is one of the topics of the present research and it will be further investigated. 
Table 2. Chemical composition of iron ores, according to their size distributions in mm, dry wt \%.

\begin{tabular}{|c|c|c|c|c|c|c|c|}
\hline Ore & Fraction & Fraction Ratio & $\mathrm{Fe}_{\text {total }}$ & $\mathrm{CaO}$ & $\mathrm{SiO}_{2}$ & $\mathrm{Al}_{2} \mathrm{O}_{3}$ & $\mathrm{MgO}$ \\
\hline \multirow{11}{*}{ Carajás } & +8 & 9.37 & 62.63 & 0.62 & 1.30 & 0.95 & 1.02 \\
\hline & $6.3-8$ & 5.54 & 60.78 & 1.72 & 1.81 & 3.02 & 0.49 \\
\hline & $5-6.3$ & 4.34 & 62.71 & 0.24 & 1.52 & 0.85 & 0.71 \\
\hline & $3.15-5$ & 11.31 & 65.62 & 0.25 & 1.54 & 0.64 & 0.40 \\
\hline & $2-3.15$ & 4.80 & 64.26 & 0.21 & 1.43 & 0.53 & 0.51 \\
\hline & $1-2$ & 14.17 & 67.55 & 0.15 & 0.66 & 0.66 & 0.43 \\
\hline & $0.5-1$ & 15.58 & 65.78 & 0.27 & 1.30 & 0.89 & 0.31 \\
\hline & $0.25-0.5$ & 10.99 & 67.12 & 0.20 & 0.77 & 1.00 & 0.56 \\
\hline & $0.125-0.25$ & 11.37 & 67.45 & 0.10 & 0.93 & 1.08 & 0.21 \\
\hline & $0.063-0.125$ & 4.02 & 68.36 & 0.08 & 0.85 & 1.04 & 0.16 \\
\hline & -0.063 & 8.51 & 68.01 & 0.10 & 0.89 & 1.15 & 0.22 \\
\hline \multirow{11}{*}{ Sukha Balka } & +8 & 11.95 & 48.41 & 0.07 & 17.40 & 0.75 & 0.73 \\
\hline & $6.3-8$ & 10.69 & 54.69 & 0.08 & 15.50 & 0.87 & 0.67 \\
\hline & $5-6.3$ & 5.25 & 59.13 & 0.08 & 14.10 & 0.75 & 0.49 \\
\hline & $3.15-5$ & 7.06 & 60.46 & 0.10 & 11.04 & 0.78 & 0.52 \\
\hline & $2-3.15$ & 6.16 & 59.52 & 0.09 & 12.52 & 0.69 & 0.61 \\
\hline & $1-2$ & 10.32 & 62.84 & 0.08 & 8.60 & 0.79 & 0.50 \\
\hline & $0.5-1$ & 7.39 & 63.05 & 0.11 & 7.87 & 0.98 & 0.41 \\
\hline & $0.25-0.5$ & 8.61 & 64.58 & 0.11 & 6.49 & 1.72 & 0.36 \\
\hline & $0.125-0.25$ & 10.08 & 64.29 & 0.12 & 6.85 & 1.61 & 0.31 \\
\hline & $0.063-0.125$ & 9.25 & 64.19 & 0.15 & 6.94 & 1.11 & 0.27 \\
\hline & -0.063 & 13.23 & 65.31 & 0.13 & 4.78 & 0.91 & 0.44 \\
\hline \multirow{11}{*}{ Zaporozhskiy } & +8 & 11.51 & 59.42 & 0.15 & 8.80 & 0.99 & 0.71 \\
\hline & $6.3-8$ & 5.42 & 58.34 & 0.28 & 9.10 & 0.82 & 0.68 \\
\hline & $5-6.3$ & 6.32 & 58.81 & 0.24 & 9.17 & 0.83 & 0.60 \\
\hline & $3.15-5$ & 9.93 & 60.88 & 0.30 & 9.51 & 1.04 & 0.80 \\
\hline & $2-3.15$ & 9.03 & 59.14 & 0.24 & 8.35 & 0.84 & 0.63 \\
\hline & $1-2$ & 15.57 & 60.19 & 0.40 & 8.20 & 1.03 & 0.90 \\
\hline & $0.5-1$ & 9.07 & 61.48 & 0.41 & 7.56 & 1.38 & 0.51 \\
\hline & $0.25-0.5$ & 8.91 & 60.86 & 0.75 & 7.00 & 1.55 & 0.51 \\
\hline & $0.125-0.25$ & 9.57 & 62.63 & 0.73 & 5.45 & 1.51 & 0.48 \\
\hline & $0.063-0.125$ & 6.13 & 63.66 & 0.89 & 5.45 & 1.40 & 0.35 \\
\hline & -0.063 & 8.55 & 63.36 & 0.91 & 5.78 & 1.46 & 0.42 \\
\hline
\end{tabular}

\subsection{Experimental Conditions}

\subsubsection{Blending}

The ores were blended into sintering mixtures to produce three compositional grades: (i) an iron-rich mixture SM-F (60.25 wt \% Fe in final sinter), (ii) a high-alumina mixture SM-A (4.92 wt \% $\left.\mathrm{Al}_{2} \mathrm{O}_{3}\right)$, and (iii) a high-silica mixture SM-S $\left(9.31 \mathrm{wt} \% \mathrm{SiO}_{2}\right)$. Fluxing with limestone was set to achieve a binary basicity $\mathrm{CaO} / \mathrm{SiO}_{2}=2$. The blending scheme is shown in Table 3. Because of the extraordinary low silica content of the samples from Carajás, which is very unusual for industrial sintering, some Zaporozhskiy ore was added to the SM-F mixture. This was meant to subsequently support the formation of secondary phases during sintering. In the SM-A blending, a mixture of Carajás and Zaporozhskiy ore was used with the addition of alumina powder. The selection of the alumina source in a fine form was based on the high concentration of $\mathrm{Al}_{2} \mathrm{O}_{3}$ in the sintering ore fines, rather than in the coarse ore particles $[25,26]$. The SM-S sintering mixture consists only of the Sukha Balka ore, fuel, and flux. 
Table 3. Sintering mixtures blending scheme, wt \%.

\begin{tabular}{ccccccc}
\hline Mixture & Carajás & Sukha Balka & Zaporozhskiy & Alumina & Limestone & Coke \\
\hline SM-F & 74.0 & - & 10.0 & - & 10.0 & 6.0 \\
SM-A & 49.2 & - & 24.0 & 3.0 & 15.0 & 8.8 \\
SM-S & - & 62.5 & - & - & 31.5 & 6.0 \\
\hline
\end{tabular}

This study focuses on examining coarse ore particle behavior as granule nuclei. Additionally, processes and phases formed in the adhering layer are of interest, so the fuel and fluxing agent, together with the alumina powder, were added as fine particles $(-0.5 \mathrm{~mm})$ to become part of the adhering layer, rather than nuclei particles of granules. In contrast to the industrial process, no return sinter was blended into the mixtures. For this reason, higher coke levels were used. For the SM-A mixture, even more coke was blended in because of the high alumina content, which deteriorates the sinter melt behavior by increasing both the melting temperature and viscosity [27].

All mixtures were prepared for sintering by means of granulation in a pelletizing disk by adding sufficient amounts of water $(\sim 7.5 \mathrm{wt} \%)$.

\subsubsection{Sintering}

Sintering trials were carried out in a laboratory sintering pot designed as a tube with a circular diameter of $100 \mathrm{~mm}$ and height of $250 \mathrm{~mm}$ while the height and diameter of the green sintering mixture column were 200 and $80 \mathrm{~mm}$, respectively. Magnetite fines were used in the form of an annular layer for the sidewall insulation. As a hearth layer, $+10-20 \mathrm{~mm}$ sinter was used. On the top, a thin coke breeze layer was added to support the ignition. The mixtures were ignited with a gas burner for $90 \mathrm{~s}$ under $2 \mathrm{kPa}$ suction. Subsequently, a working suction of $5 \mathrm{kPa}$ was maintained. During the sintering, the thermal profiles were recorded with a PtRh10-Pt thermocouple installed in the middle of the sinter bed and a NiCr-NiAl thermocouple in the wind box. The sinter pot arrangement is illustrated in Figure 1.

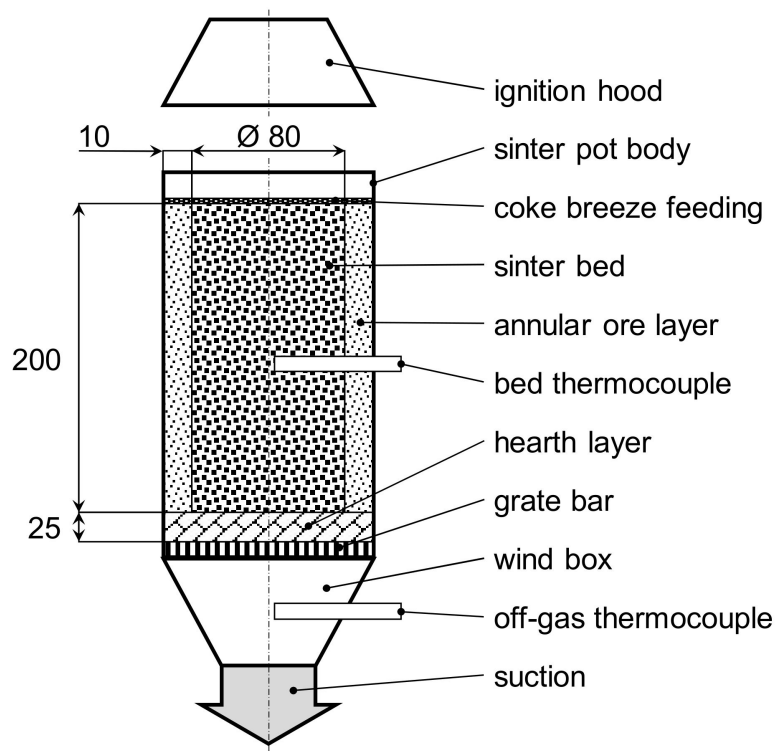

Figure 1. Sinter pot arrangement (dimensions in $\mathrm{mm}$ ).

A comparison of the time-dependent sintering temperature profiles of the mixtures is given in Figure 2. Sintering of the mixtures SM-S and SM-F behaved very similarly. The difference was only in the maximum temperature, which was lower in the case of SM-S. The same coke amount was added

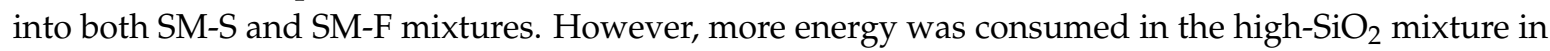


decomposing the large amount of limestone. The highest peak temperature was reached in sintering the SM-A mixture, where the highest level of coke was added. In addition, the temperature profile of the high- $\mathrm{Al}_{2} \mathrm{O}_{3}$ mixture is clearly broader, which indicates a broad flame front.

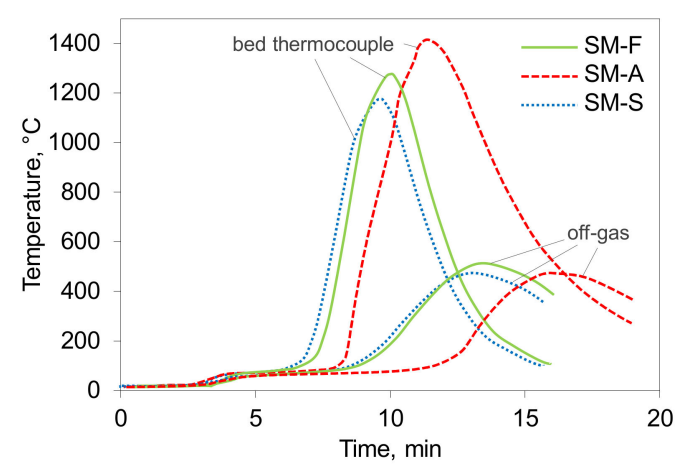

Figure 2. Temperature profiles recorded during pot sintering. Higher curves apply for the thermocouple in bed and lower for off-gas.

\subsubsection{Analytical and Evaluating Methods}

Raw ore samples were examined using a Derivatograph C/PC thermal analyzer (MOM, Budapest, Hungary). Samples ground to $-40 \mu \mathrm{m}$ were each placed in an alumina crucible and heated in air from room temperature up to $1000^{\circ} \mathrm{C}$ using a heating rate of $10^{\circ} \mathrm{C} / \mathrm{min}$.

Fresh sinter cakes from the laboratory pot were shattered to get smaller pieces of the sinter. For mineralogical examination, representative samples from each iron ore and sinter cake were taken by quartering until a sufficient amount of the sample (approximately $40 \mathrm{~g}$ ) was reached. At least two samples were taken from each sinter. These were prepared by mounting into epoxy resin and polishing. First, the basic observation of the samples was carried out with a Leica DM4500P optical microscope (Leica Camera AG, Wizlar, Germany). Afterwards, a MIRA3 TESCAN (TESCAN, Brno, Czech Republic) scanning electron microscope with Energy Dispersive Spectroscopy (EDS) (Oxford Instruments, Abington, UK) was used for detailed determination of the phase compositions. Note that, for hydrated minerals, the EDS calculations do not include the structurally bonded water. For magnetite and ferrites, all iron was calculated as $\mathrm{Fe}^{3+}$, while, for glass, wüstite and silicates as $\mathrm{Fe}^{2+}$.

Additionally, X-ray Powder Diffraction (XRD) was applied for the phase analysis of the fresh sinter cakes. A representative sample of each type of sinter was first crushed into coarse fragments, which was followed by grinding in a McCrone Micronizing Mill. With about $0.5 \mathrm{~g}$ of each powdered and homogenized sinter cake, a powder diffraction experiment was carried out. The experiments were accomplished with a Stoe MultiPurpose Diffractometer System in Bragg-Brentano configuration (University of Innsbruck, Innsbruck, Austria), which was equipped with a primary beam $\mathrm{Ge}(111)$-monochromator to ensure $\mathrm{Co}-\mathrm{K} \alpha_{1}$ radiation and a Dectris Mythen $1 \mathrm{~K}$ Detector (DECTRIS Ltd., Philadelphia, PA, USA). The X-ray tube was operated with $40 \mathrm{kV}$ and $30 \mathrm{~mA}$. Diffraction data from each sample were collected at an ambient temperature in a sequence of eight measurements with a $2 \theta$ range between $2^{\circ}$ and $140^{\circ}$, a step size of $0.015^{\circ}$, and an exposure time of seven hours in total. The obtained diffractograms of the measurements were summed and used for phase identification with the software DIFFRAC ${ }^{\text {lus }}$ Evaluation Package (version 4.2.1, Bruker: Billerica, MA, USA) [28] in combination with the ICDD PDF-4+ database (2018) [29]. Furthermore, Le-Bail-fits were performed with TOPAS 4.2 (Version 4.2, Bruker: Billerica, MA, USA) [30]. For the modelling of the peak profiles, a Thompson-Cox-Hastings profile function [31] was employed. The background curve was simulated with sixth-order Chebyshev polynomials.

Thermodynamic calculations of the reaction heat were performed using the HSC Chemistry software (Version 5, Outokumpu Research Oy, Pori, Finland). 


\section{Results}

\subsection{Ore Mineralogy}

The behavior of the ores during heating was studied using thermogravimetric analysis (TG) in air, as shown in Figure 3. From the chemical composition shown in Table 1, very low FeO contents suggest that the iron in ores occurs mainly as hematite, while higher ignition losses indicate the presence of goethite. This was confirmed by the TG analysis, where distinct weight loss in the temperature range of $250{ }^{\circ} \mathrm{C}$ to $350{ }^{\circ} \mathrm{C}$ was observed. The goethite content in the Carajás ore can be estimated at $\sim 15 \mathrm{wt} \%$ following the TG analysis. Moreover, though only slight, the curve shift indicates the oxidation of a low amount of magnetite, which applies for the Brazilian as well as both Ukrainian ore samples.

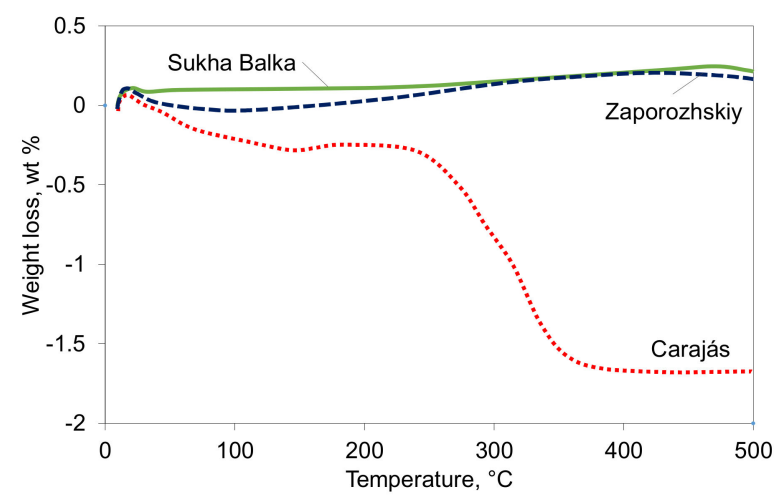

Figure 3. Characterization of the studied iron ores with TG analysis.

Basic textural characteristics of the studied iron ores are shown in Figure 4.

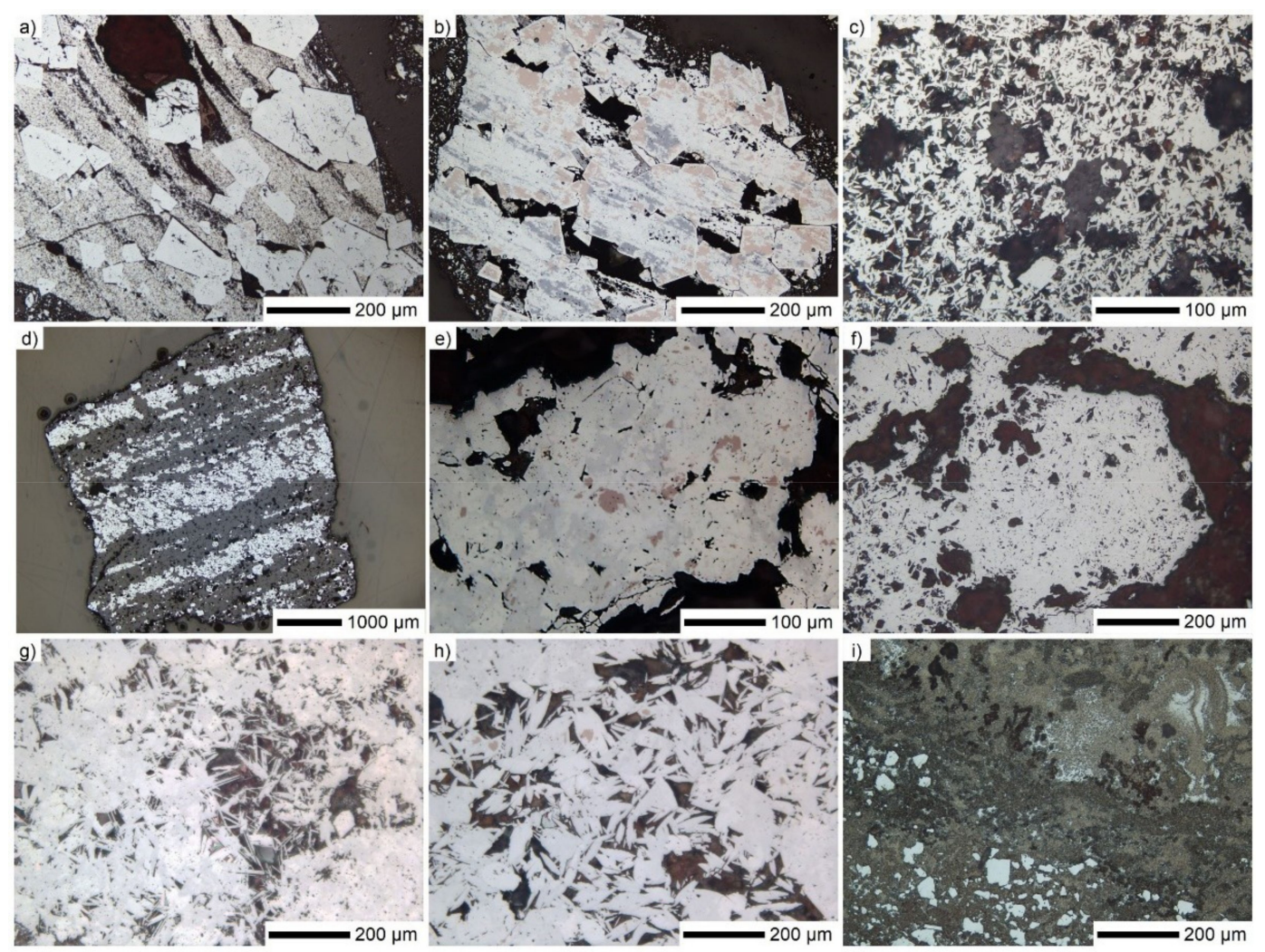

Figure 4. Reflected light micrographs of iron ores: (a-c) Carajás, $(\mathbf{d}-\mathbf{f})$ Sukha Balka, and (g-i) Zaporozhskiy. 
The Carajás iron ore consisted mainly of different morphological varieties of hematite. The most widespread was martite, which commonly comes with sharply-shaped crystals in which traces of magnetite were still observable. The martite crystals may appear as a component of mixed ore grains cemented with very fine crystalline porous hematite aligned in bands (Figure 4a). The phase assemblage of residual magnetite (pink-brown) together with vitreous goethite (gray) replacing the martite mass formed within the martite crystals (white) (Figure $4 b$ ).

As mentioned by the TG analysis, there was a significant amount of goethite present in the ore from Carajás, which also appeared in a massive, circular form enclosing the martite phase. Less common was microplaty hematite appearing in clusters (Figure 4c). Gangue minerals were present as single grains, rather than combined with iron-based crystals.

Coarse grains of Sukha Balka ore clearly showed the typical banded iron formation microstructure with alternating hematite (white) and quartz (dark grey) layers (Figure 4d). The hematite bands consisted of martite crystals (white and light gray) with magnetite traces (pink-brown) (Figure 4e), which sometimes comes with larger subhedral aggregations (Figure 4f). The quartz bands exhibited porosity.

Similar to Sukha Balka, regular hematite/quartz banding was characteristic for the Zaporozhskiy ore. On the other hand, the mineralogy of smaller grains was much more variable in the latter. The different-sized martite grains were complemented with a spectrum of microplaty hematite and specularite with voids between the crystals (Figure $4 \mathrm{~g}$ ). Whole ore grains consisted of bands of massive martite and (rounded) specularite, which was partially combined with fine martite showing magnetite traces (Figure $4 \mathrm{~h}$ ). The presence of ochreous goethite (various shades of brown) was unique such as having embedded martite and fine hematite crystals (white) (Figure 4i). Furthermore, in larger ore grains, quartz was almost always bonded with hematite. In smaller-size fractions, the gangue appeared as single grains. In both Sukha Balka and Zaporozhskiy ores, some subhedral pyrite crystals (about $100 \mu \mathrm{m}$ ) were observed.
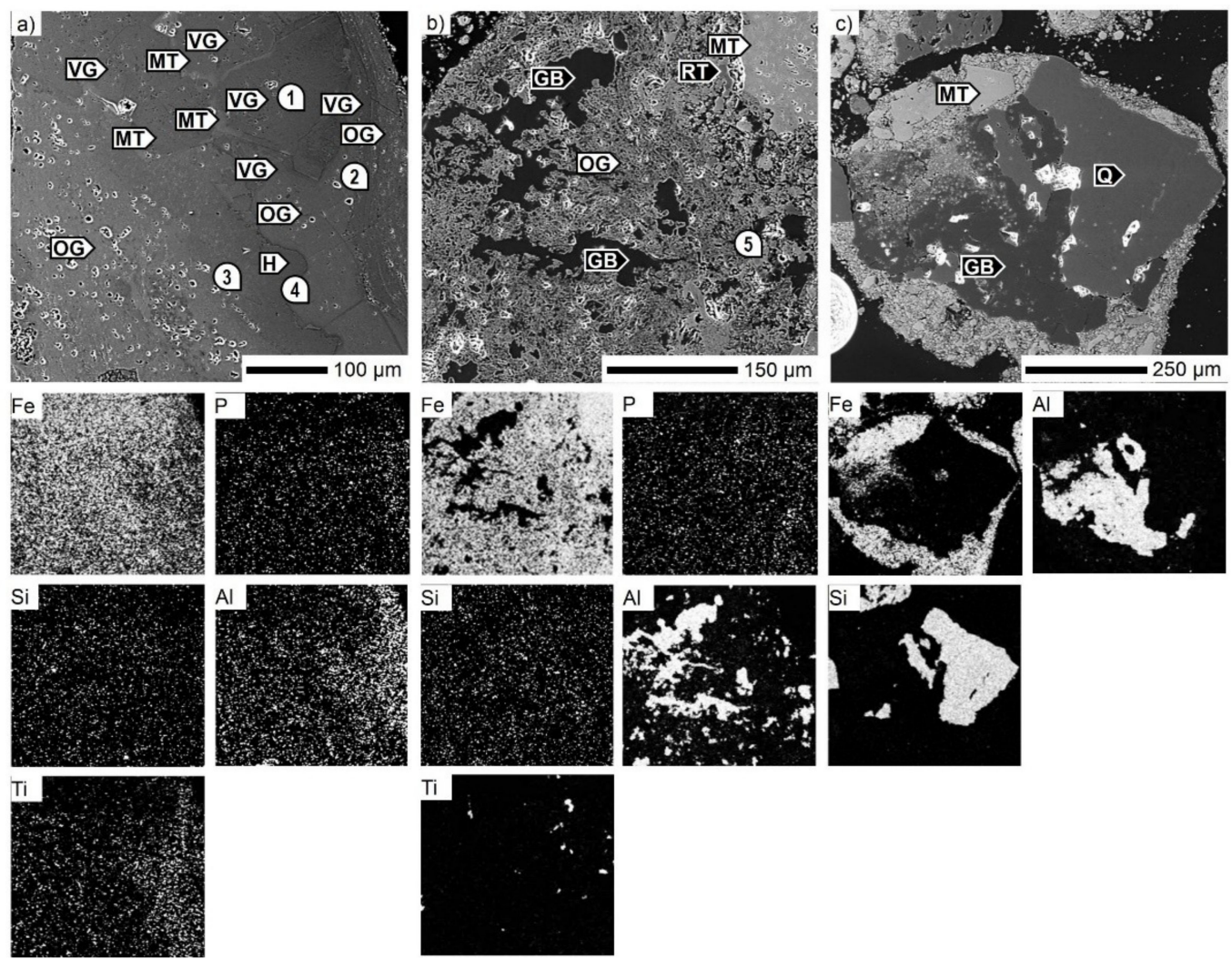

Figure 5. SEM micrographs of the Carajás ore particles. GB: gibbsite, H: hematite (microporous), MT: martite, OG: ochreous goethite, Q: quartz, RT: rutile, VG: vitreous goethite, 1-5—see Table 4. 
Table 4. EDS analysis from Figure 5, wt \%.

\begin{tabular}{|c|c|c|c|c|c|c|}
\hline Point & $\mathrm{Fe}_{2} \mathrm{O}_{3}$ & $\mathrm{SiO}_{2}$ & $\mathrm{Al}_{2} \mathrm{O}_{3}$ & $\mathrm{TiO}_{2}$ & $\mathbf{P}_{2} \mathrm{O}_{5}$ & Phase \\
\hline 1 & 98.3 & 1.1 & 0.3 & - & 0.3 & $\begin{array}{l}\text { vitreous } \\
\text { goethite }\end{array}$ \\
\hline 2 & 86.6 & 0.6 & 5.8 & 4.1 & 2.9 & $\begin{array}{l}\text { vitreous } \\
\text { goethite }\end{array}$ \\
\hline 3 & 96.7 & 1.2 & 1.0 & - & 1.1 & $\begin{array}{l}\text { ochreous } \\
\text { goethite }\end{array}$ \\
\hline 4 & 92.7 & 0.6 & 3.0 & - & 3.7 & $\begin{array}{c}\text { ochreous } \\
\text { goethite }\end{array}$ \\
\hline 5 & 96.6 & 0.6 & 1.3 & 0.7 & 0.8 & $\begin{array}{l}\text { ochreous } \\
\text { goethite }\end{array}$ \\
\hline
\end{tabular}

Although the gangue components in the Carajás ore were minor, there was a wide distribution of different phases. Chemical examination of a goethite grain is presented in Figure 5a. As shown, there were more goethite varieties, which differ from each other due to the concentration of the impurity constituents. On the right, there are layers of thin ochreous goethite alternating with thicker vitreous goethite with varying contents of $\mathrm{Al}_{2} \mathrm{O}_{3}, \mathrm{SiO}_{2}, \mathrm{TiO}_{2}$, and $\mathrm{P}_{2} \mathrm{O}_{5}$, where, except for $\mathrm{SiO}$, the impurity content decreases toward the grain center. The crystal shapes are defined by martite edges, while the rest of the crystals were partially replaced with goethite. The last one mentioned was the purest goethite type, with only minor $\mathrm{SiO}_{2}$ contents, which was present almost homogeneously in all goethite layers. Besides Al-Ti-Si-P-bearing goethite, the following typical gangue minerals were detected using EDS: gibbsite $\mathrm{Al}(\mathrm{OH})_{3}$, rutile $\mathrm{TiO}_{2}$ and quartz, which was the main gangue mineral phase (Figure $5 b, c)$.
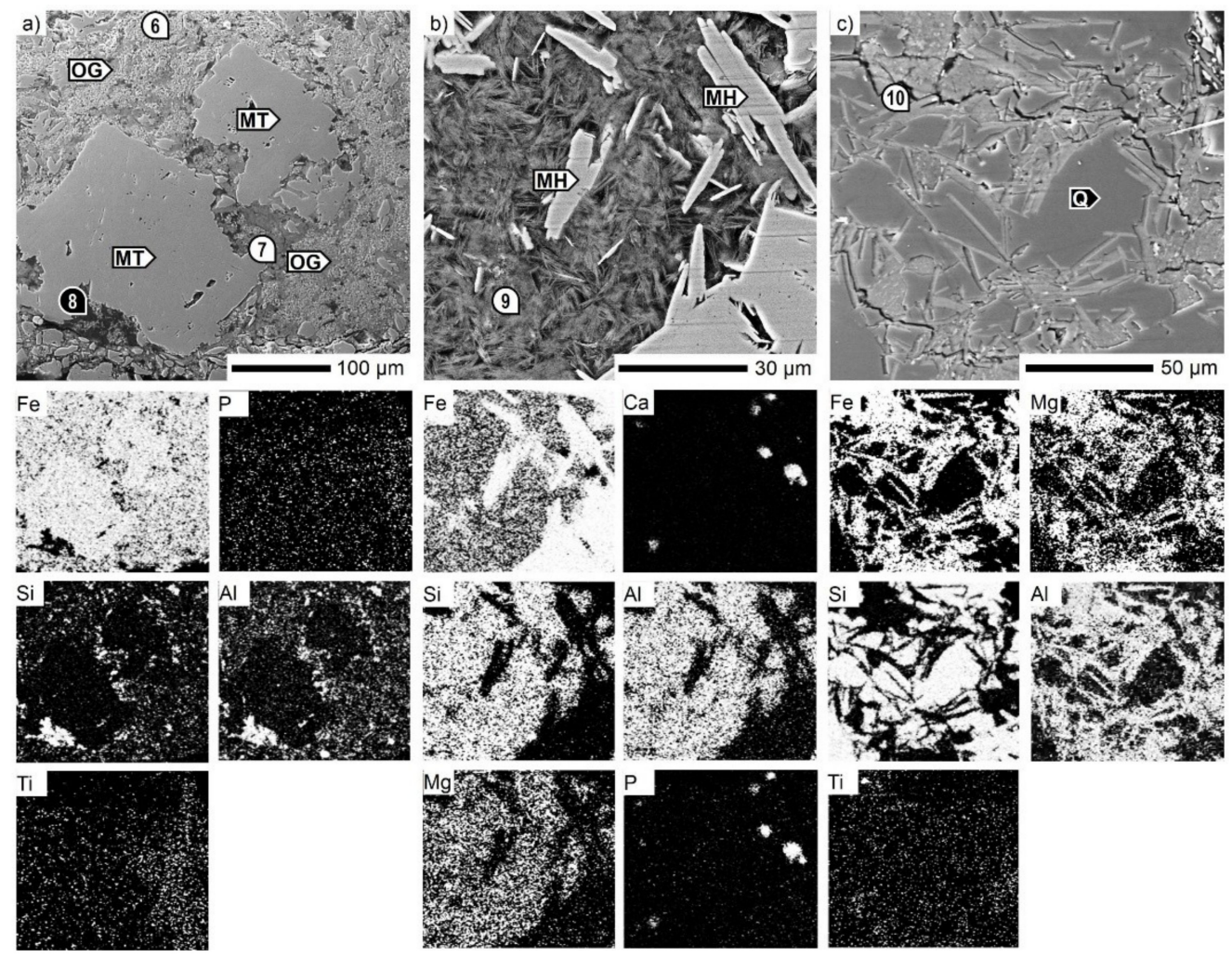

Figure 6. SEM micrographs of the (a) Sukha Balka ore (b) and (c) Zaporozhskiy ore. MH: microplaty hematite, MT: martite, OG: ochreous goethite, Q: quartz, 6-10—see Table 5. 
Table 5. EDS analysis from Figure 6, wt \%.

\begin{tabular}{|c|c|c|c|c|c|}
\hline Point & $\mathrm{Fe}_{2} \mathrm{O}_{3}$ & $\mathrm{SiO}_{2}$ & $\mathrm{Al}_{2} \mathrm{O}_{3}$ & $\mathrm{MgO}$ & Phase \\
\hline 6 & 94.3 & 2.9 & 2.8 & - & $\begin{array}{l}\text { ochreous } \\
\text { goethite * }\end{array}$ \\
\hline 7 & 96.7 & 2.1 & 1.2 & - & $\begin{array}{l}\text { ochreous } \\
\text { goethite * }\end{array}$ \\
\hline 8 & 1.9 & 53.4 & 44.7 & - & kaolinite \\
\hline 9 & 41.0 & 28.9 & 20.7 & 9.3 & chlorite \\
\hline 10 & 35.5 & 32.7 & 21.1 & 10.7 & chlorite \\
\hline
\end{tabular}

${ }^{*} \mathrm{P}_{2} \mathrm{O}_{5}$ content difficult to quantify.

The regular martite/quartz banded microstructure within the Sukha Balka ore was supplemented with $\mathrm{Si}-\mathrm{Al}-\mathrm{P}$-bearing ochreous goethite. Another $\mathrm{Al}_{2} \mathrm{O}_{3}$ source in the form of kaolinite $\mathrm{Al}_{2} \mathrm{Si}_{2} \mathrm{O}_{5}(\mathrm{OH})_{4}$ was also identified (Figure $6 \mathrm{a})$. In the case of Zaporozhskiy ore, chlorite $(\mathrm{Fe}, \mathrm{Mg}, \mathrm{Al})_{6}(\mathrm{Si}, \mathrm{Al})_{4} \mathrm{O}_{10}(\mathrm{OH})_{8}$ minerals were the carriers of $\mathrm{SiO}_{2}, \mathrm{Al}_{2} \mathrm{O}_{3}$, and $\mathrm{MgO}$. The platy morphology of chlorite occurring together with microplaty hematite and quartz is shown in Figure $6 \mathrm{~b}, \mathrm{c}$, respectively. In addition, phosphorus $\mathrm{P}_{2} \mathrm{O}_{5}$ in the form of hydroxylapatite $\mathrm{Ca}_{5}\left(\mathrm{PO}_{4}\right)_{3}(\mathrm{OH})$ was also detected (Figure $6 \mathrm{~b}$ ).

\subsection{Iron-Rich Ore Sinter}

For the SM-F mixture, two sintering ores with different characteristics were used including Carajás and Zaporozhskiy iron ores. The textural features related to these ores were also studied. The latter is only in the minor quantity. A large quartz particle (as part of the hematite/quartz alternating bands) was identified within the SM-F sinter sample in Figure 7a where the relationship between the unreacted siliceous core and the associated sinter matrix is observed. As shown, the quartz was thermally affected but not assimilated. Thus, the nucleus boundary is sharp, as indicated by the element distribution maps. The sinter matrix consisted of magnetite with its glassy phase as an intercrystalline space filler, which also accumulated $\mathrm{CaO}$. However, the very low basicity did not allow any other phase to form other than the one mentioned. The magnetite/glass microstructure also dominated the contact area of Carajás coarse ore and the related sinter matrix in Figure $7 \mathrm{~b}$. Some martitic hematite was present. In contrast to the Zaporozhskiy ore relict, the Carajás core seemed to be fully reacted. All hematite was reduced to magnetite, and $\mathrm{CaO}$ was also part of the glassy phase within the formerly coarse ore particle. The $\mathrm{Al}_{2} \mathrm{O}_{3}$ concentration was higher in the surrounding sinter matrix, rather than within the assimilated coarse ore. Lastly, the basicity of the sinter matrix was higher compared to the nucleus with 0.8 to 0.4 , respectively. In general, the boundary of the coarse ore mass was not pronounced and could only be defined by its chemical and phase composition. The most obvious characteristic of the Carajás ore in the sinter consisted of clusters of larger pores close to each other.

The photomicrograph in Figure 7c shows a region where smaller Carajás ore particles were assimilated. In this scenario, the sinter matrix with the highest basicity of about 1.5 consisted of anhedral SFCA prisms among the magnetite crystals with glassy filling and some martitic hematite on the edges. From the chemical point of view, the distribution of $\mathrm{Al}_{2} \mathrm{O}_{3}$ was the most interesting. The sources were the aluminous ore particles, which also enriched the areas in their vicinity. There were also some elongated crystals of gehlenite $\mathrm{Ca}_{2} \mathrm{Al}(\mathrm{Al}, \mathrm{Si}) \mathrm{O}_{7}$ in the alumina-rich regions.

The average chemical composition of the secondary phases analyzed in the sinter matrix is summarized in Table 6. Secondary magnetite incorporated small amounts of $\mathrm{CaO}, \mathrm{SiO}_{2}, \mathrm{Al}_{2} \mathrm{O}_{3}$, and $\mathrm{MgO}$, while a very small volume of martitic hematite was almost without any impurities. Note that the glass near the quartz from the Zaporozhskiy ore relict consisted of $90 \mathrm{wt} \% \mathrm{SiO}_{2}$ with small amounts of $\mathrm{CaO}$ and traces of iron oxide. Titanium and phosphorus, which are typical elements for the Carajás ore, were identified only in the glass. 

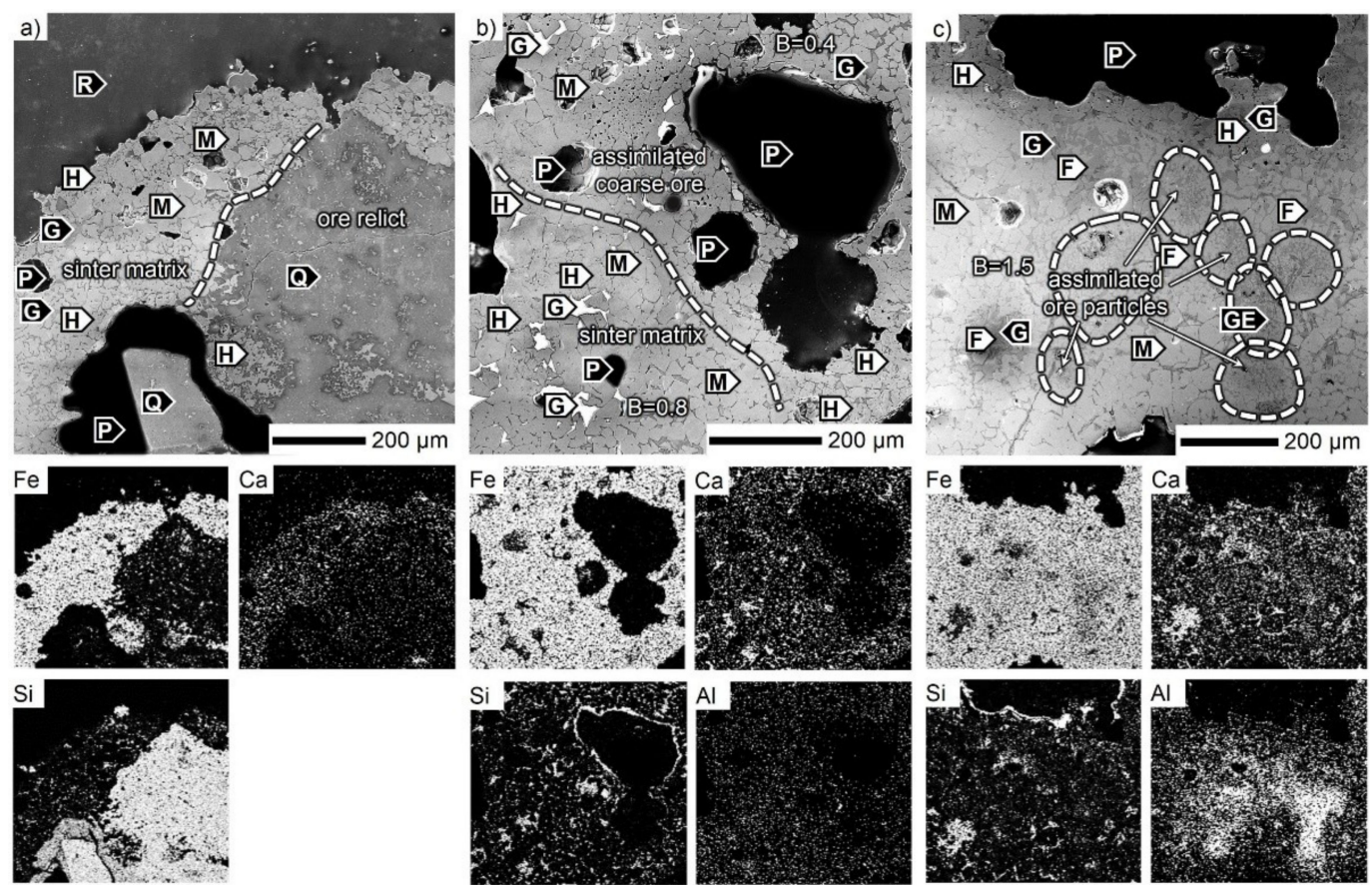

Figure 7. SEM micrographs of the SM-F sinter. B: $\mathrm{CaO} / \mathrm{SiO}_{2}$, F: SFCA, G: glass, GE: gehlenite, $\mathrm{H}$ : hematite, M: magnetite, P: pore, Q: quartz, R: resin.

Table 6. Average chemical composition of the secondary phases in SM-F sinter, wt \%.

\begin{tabular}{cccccccccc}
\hline Phase & $\mathrm{Fe}_{2} \mathrm{O}_{3}$ & $\mathrm{CaO}$ & $\mathrm{SiO}_{2}$ & $\mathrm{Al}_{2} \mathbf{O}_{3}$ & $\mathbf{M g O}$ & $\mathrm{TiO}_{2}$ & $\mathrm{~K}_{\mathbf{2}} \mathbf{O}$ & $\mathbf{P}_{2} \mathrm{O}_{5}$ & $\mathbf{F e O}$ \\
\hline magnetite & 99.1 & 0.3 & 0.4 & 0.3 & 0.2 & - & - & - & - \\
hematite & 99.8 & - & 0.2 & - & - & - & - & - & - \\
SFCA & 64.9 & 15.9 & 6.1 & 13.1 & - & - & - & - & - \\
glass & - & 36.6 & 37.2 & 6.2 & - & 1.5 & 0.3 & 1.1 & 17.2 \\
\hline
\end{tabular}

The XRD phase analysis of SM-F (Figure 8) identified magnetite and hematite as the major sinter phases. Distinct crystallinity is presumed due to the sharp and well-defined peaks of both phases. The slightly unlabeled peaks in the $2 \theta$ range from $30^{\circ}$ to $45^{\circ}$ provides an indication of the presence of SFCA. However, no decisive correlation of these peaks to a certain phase could be confirmed.

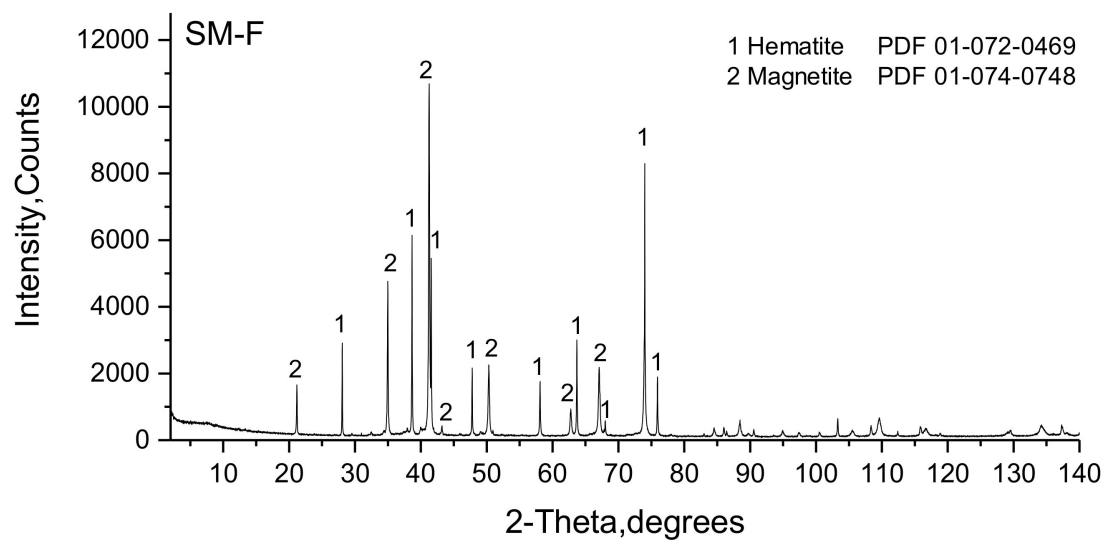

Figure 8. Powder diffractogram of the SM-F sinter.

\subsection{High-Alumina Iron Ore Sinter}

Similar to SM-F, in the SM-A sinter, the impact of the two ores was investigated. The microstructure of the Carajás assimilated coarse ore is shown in Figure 9a. The Carajás coarse relicts 
showed higher porosity, which is a typical feature. Because of the full assimilation, there were only small differences in the chemical composition between the assimilated coarse ore and the sinter matrix. Deep inside the former nucleus, calcium ferrites were present together with the glass. Besides porosity, the $\mathrm{Al}_{2} \mathrm{O}_{3}$ concentration also determined the coarse ore boundary, which was lower compared to the related sinter matrix. The other ore type relict from Zaporozhskiy also showed a higher assimilation level (Figure 9b). Besides $\mathrm{SiO}_{2}$, the $\mathrm{CaO}$ and $\mathrm{Al}_{2} \mathrm{O}_{3}$ concentrations were also elevated in the marginal parts of the nucleus ore particles. Magnetite bands as relicts of the former hematite (martite) arrangement together with SFCA in the glassy matrix built up the microstructure. A preserved hematite region was observed in the ore core, where the microplaty habitus was distinguishable (not seen in the figure). In this case, no large quartz particles were found. The rest of the sinter matrix in Figure $9 \mathrm{~b}$ consisted of a magnetite-SFCA phase assemblage. The microstructure with a ferrous ore core reduced to wüstite is presented in Figure 9c. Wüstite was accompanied only with glass, which accumulated $\mathrm{CaO}, \mathrm{SiO}_{2}$, and $\mathrm{Al}_{2} \mathrm{O}_{3}$. The highest $\mathrm{Al}_{2} \mathrm{O}_{3}$ concentration was observed in the sinter matrix within the magnetite and the glass phase. After the magnetite transition zone, SFCA crystals formed in the area with the highest $\mathrm{CaO}$ concentration.
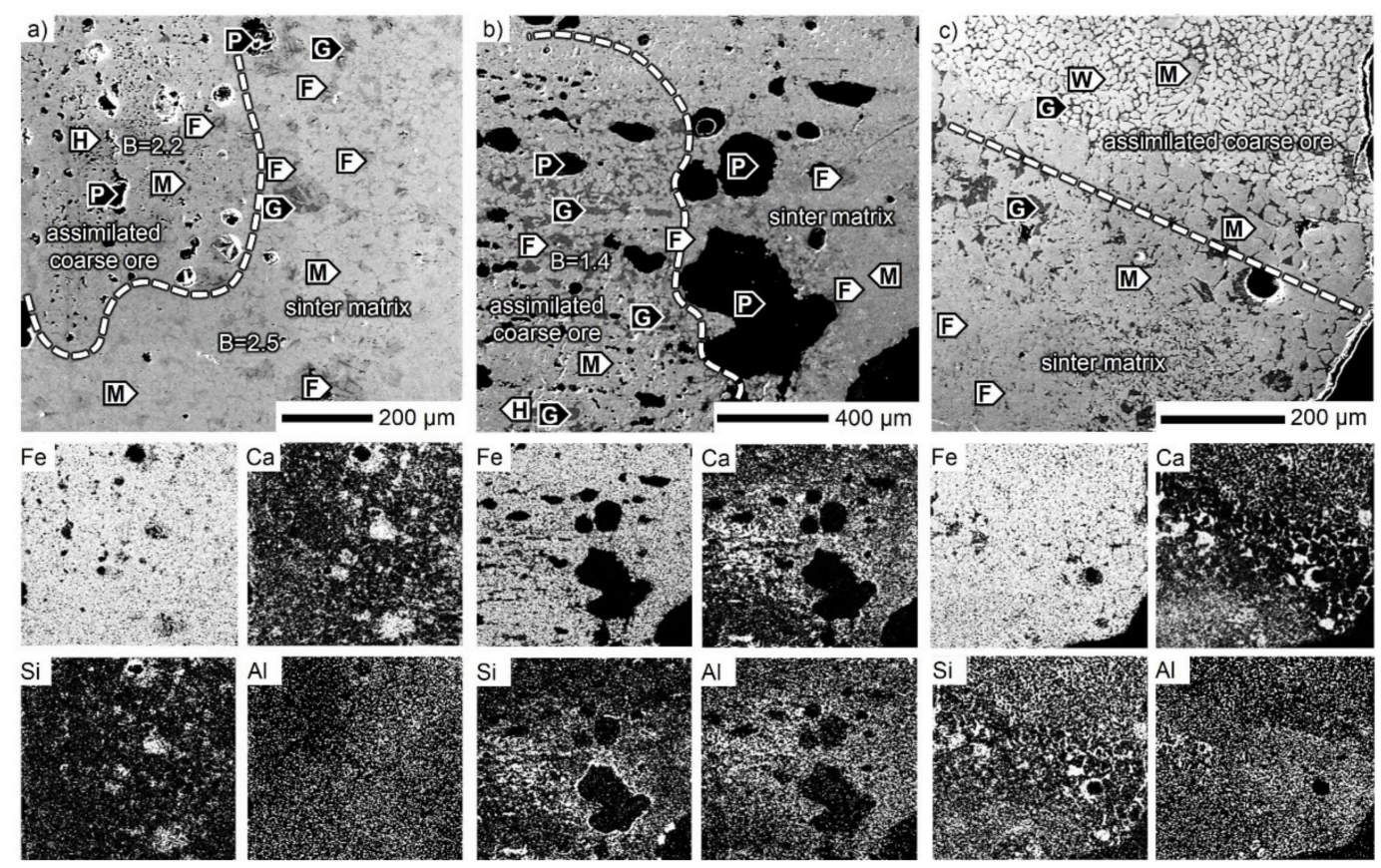

Figure 9. SEM micrographs of the SM-A sinter. B: $\mathrm{CaO} / \mathrm{SiO}_{2}$, F: SFCA, G: glass, $\mathrm{H}$ : hematite, M: magnetite, P: pore, W: wüstite.

Despite the high temperature reached in sintering, some SFCA-I crystals, known as the low-temperature ferrite type, were preserved in the microstructure of the SM-A sinter. As illustrated in Figure 10a, they were always part of the SFCA/SFCA-I phase assemblage, where the thin SFCA-I crystals were coated with SFCA [32]. In addition to the previously mentioned phases, gehlenite $\mathrm{Ca}_{2} \mathrm{Al}(\mathrm{Al}, \mathrm{Si}) \mathrm{O}_{7}$ formed in the alumina-rich areas together with magnetite as the main phase (Figure 10b). The basicity of these areas was about two, and the content of $\mathrm{Al}_{2} \mathrm{O}_{3}$ and $\mathrm{CaO}$ was almost the same at $\sim 16-17 \mathrm{wt} \%$. A further peculiarity of the SM-A sinter was the presence of reduced phases. Wüstite and traces of metallic iron were identified.

Examining the chemical composition of the phases in the SM-A sinter (Table 7), elevated contents of alumina were detected in other phases as well. In addition to its iron oxide components, magnetite also contains larger amounts of $\mathrm{CaO}, \mathrm{MgO}$, and $\mathrm{Al}_{2} \mathrm{O}_{3}$, and, in this case, the highest content of alumina reached $3.3 \mathrm{wt} \%$. Wüstite was present only in a few areas and accumulated significantly lower alumina, but more than $1 \mathrm{wt} \% \mathrm{MgO}$ on average. The SM-A sinter matrix was rich in SFCA phases of 
which two compositional types formed with $\mathrm{Al}_{2} \mathrm{O}_{3}$ contents of about $\sim 6$ and $\sim 10 \mathrm{wt} \%$. The latter was also richer in $\mathrm{SiO}_{2}$. A few analyzed SFCA-I crystals were also higher in alumina, up to $5.6 \mathrm{wt} \%$. The chemical composition of the glass was highly dependent on the local conditions, and, therefore, two types are presented in Table 7. While the first collected more minor gangue impurities with only limited alumina content, the second was of high-alumina nature (analyzed in the wüstite area in Figure 9c).
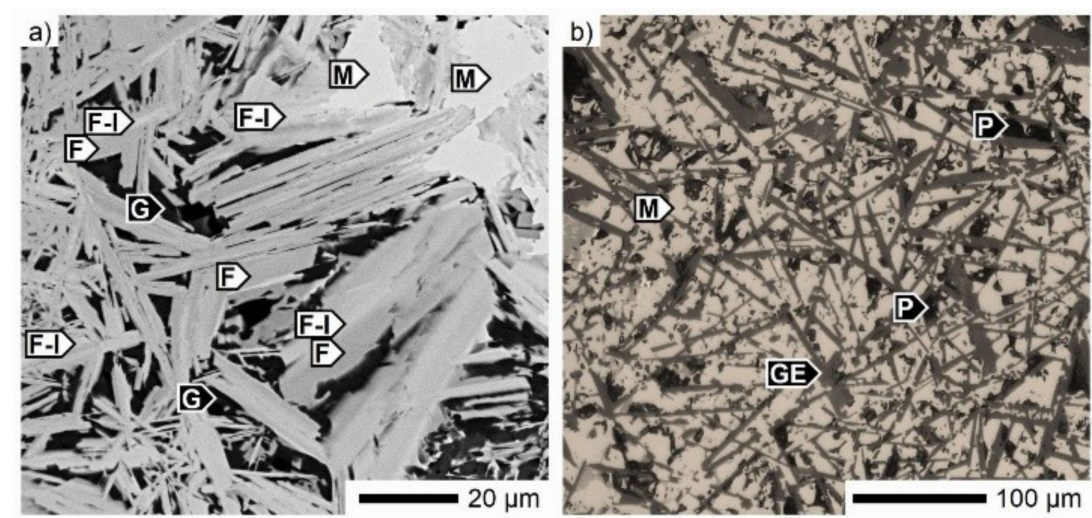

Figure 10. Micrographs of the SM-A sinter microstructure: (a) calcium ferrites assemblage (SEM) and (b) magnetite-gehlenite (reflected light). F: SFCA, F-I: SFCA-I, G: glass, GE: gehlenite M: magnetite, P: pore.

Table 7. Average chemical composition of the secondary phases in SM-A sinter, wt \%.

\begin{tabular}{|c|c|c|c|c|c|c|c|c|c|c|}
\hline Phase & $\mathrm{Fe}_{2} \mathrm{O}_{3}$ & $\mathrm{CaO}$ & $\mathrm{SiO}_{2}$ & $\mathrm{Al}_{2} \mathrm{O}_{3}$ & $\mathrm{MgO}$ & $\mathrm{TiO}_{2}$ & $\mathrm{~K}_{2} \mathrm{O}$ & $\mathrm{Na}_{2} \mathrm{O}$ & $\mathrm{P}_{2} \mathrm{O}_{5}$ & $\mathrm{FeO}$ \\
\hline$\underset{*}{\operatorname{magnetite}}$ & 94.8 & 1.7 & - & 2.4 & 1.0 & - & - & - & - & - \\
\hline wüstite & - & 0.5 & - & 0.5 & 1.2 & - & - & - & - & 97.9 \\
\hline hematite & 98.6 & - & - & 1.4 & - & - & - & - & - & - \\
\hline $\operatorname{SFCA}(a) *$ & 70.5 & 16.9 & 6.0 & 6.5 & 0.1 & 0.1 & - & - & - & - \\
\hline SFCA (b) * & 64.8 & 15.0 & 8.0 & 10.6 & - & - & - & - & - & - \\
\hline SFCA-I * & 80.9 & 11.0 & 1.9 & 4.8 & 1.0 & - & - & - & - & - \\
\hline glass (a) & - & 42.7 & 33.4 & 4.3 & - & 1.6 & 1.7 & 0.3 & 2.4 & 13.0 \\
\hline glass (b) & - & 42.3 & 17.5 & 19.5 & - & - & - & - & - & 20.7 \\
\hline
\end{tabular}

The phase composition of SM-A determined by means of XRD (Figure 11) confirmed the major phases of hematite and magnetite, and also another iron oxide, wüstite. The presence of larnite and quartz was detected as well. SFCA and SFCA-I could not be clearly identified, but their occurrence is assumed due to the unmarked low intense peaks in the $2 \theta$-range between $10-15^{\circ}$ and $30-45^{\circ}$.

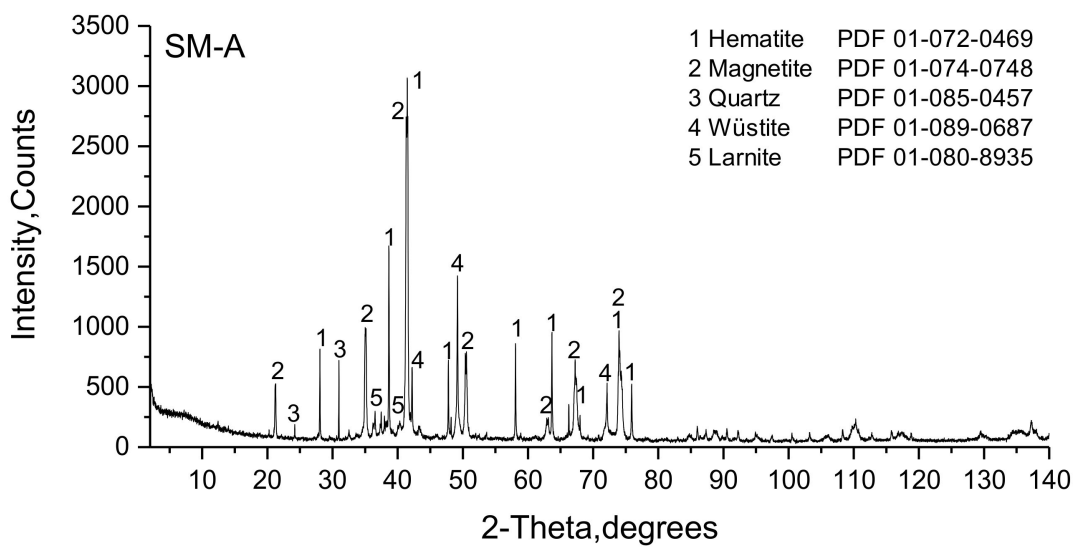

Figure 11. Powder difractogram of the SM-A sinter. 


\subsection{High-Silica Iron Ore Sinter}

During sintering of the SM-S mixture, the impact of Sukha Balka coarse ores was studied. A coarse ore particle with preserved hematite/quartz bands is shown in Figure 12a. In the original hematite band, an approximate $200 \mu \mathrm{m}$ thick layer, which was reduced to magnetite was observed in the vicinity of the sinter matrix. Towards the sinter matrix, another thin layer of calcium ferrites formed a transition zone. In the quartz band, a $\sim 150 \mu \mathrm{m}$ thick layer of thermally-affected quartz without porosity was followed by a very thin hematite-magnetite-pseudo-wollastonite layer. In contrast to the marginal parts, the bulk of the ore was porous, and the voids between single quartz grains were especially well observed. Some $\mathrm{Al}_{2} \mathrm{O}_{3}$ was mixed into gangue phases in the bulk of the ore. The sinter matrix was dominated by calcium ferrites: SFCA, SFCA-I, and dicalcium ferrite supplemented with dicalcium silicate. In the upper left corner of Figure 12a, traces of assimilated limestone particles caused high basicity of about $\sim 10$. In addition, the presence of $\mathrm{MgO}$ was detected (occurring in regions with the lowest Fe signal). The siliceous transition zone polished along the ore surface in Figure $12 \mathrm{~b}$ seemed to be fully reacted, which was also confirmed by the $\mathrm{CaO}$ distribution throughout the whole scanned area. This consisted of a mixture of silicates with elongated kirschsteinite $\mathrm{CaFeSiO}_{4}$ crystals, square-shaped iron-calcium olivine $(\mathrm{Ca}, \mathrm{Fe}, \mathrm{Mg})_{2}(\mathrm{Si}, \mathrm{Al}) \mathrm{O}_{4}$, and secondary magnetite crystals, which were also distributed among the silicates in the bulk ore. The related sinter matrix consisted of calcium ferrites $\left(\mathrm{Ca}_{2} \mathrm{Fe}_{2} \mathrm{O}_{5}, \mathrm{SFCA}\right)$, larnite, and magnetite. Another silicate-based transition zone is shown in Figure 12c, where the ore core still consisted of quartz. Tabular iron-calcium olivines $(\mathrm{Ca}, \mathrm{Fe}, \mathrm{Mg})_{2}(\mathrm{Si}, \mathrm{Al}) \mathrm{O}_{4}$ crystallized subhedrally in the pores of the marginal ore part. The assimilated ore boundary was made up of secondary magnetite. The SFCA phase supplemented with larnite dominated the surrounding sinter matrix. However, the $\mathrm{SiO}_{2}$ distribution map shows strict $\mathrm{SiO}_{2}$ presence only within the silicates while the SFCA spots are almost silica free.
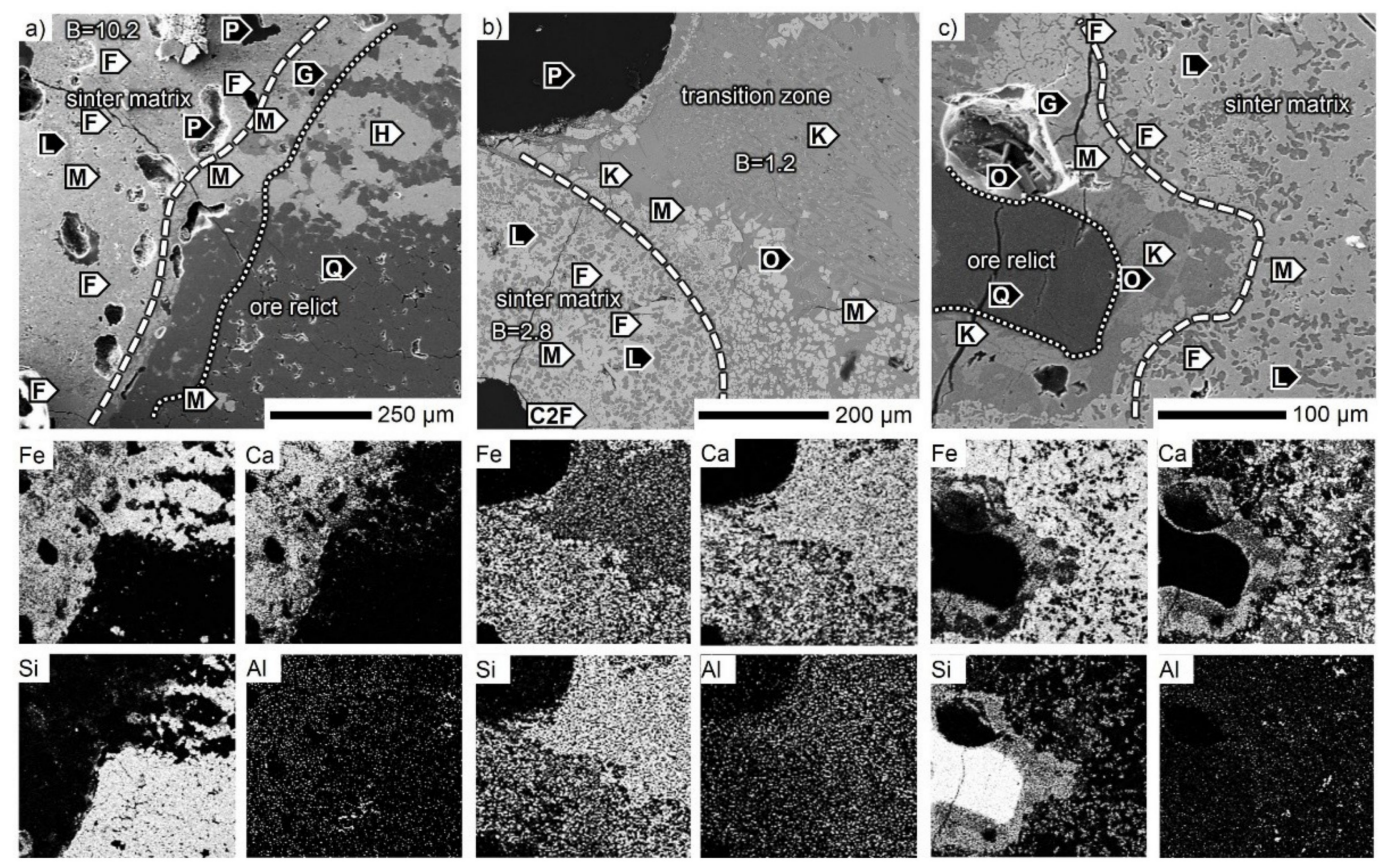

Figure 12. SEM micrographs of the $\mathrm{SM}-\mathrm{S}$ sinter. $\mathrm{B}-\mathrm{CaO} / \mathrm{SiO}_{2}, \mathrm{C} 2 \mathrm{~F}-$ dicalcium ferrite, F-SFCA, G-glass, H-hematite, $\mathrm{K}$-kirschsteinite, L-larnite, $\mathrm{M}$-magnetite, $\mathrm{O}$-Fe-Ca-olivine, $\mathrm{P}$-pore, Q-quartz.

Furthermore, in the transition zone, other silicates were identified as well (Figure 13a). Instead of the olivine phase, pseudo-wollastonite $\mathrm{CaSiO}_{3}$ was the abundant compound supplemented with fine magnetite and dendritic hedenbergite. There were three different identifiable zones including the unreacted core, which is the penetrated area, and, at the same time, the reduced zone, 
and the rest of the sinter matrix. The layers formed during the coarse ore assimilation process are observed in Figure 13b. In this scenario, no quartz band was present. As seen, only the marginal parts were reduced from hematite to magnetite, but the whole ore body was clearly affected. Large cracking occurred throughout the ore body during the sintering.

In the sinter matrix, which was mostly of higher basicity, four calcium ferrite types were identified, which are also listed in Table 8. There were fewer SFCA-I crystals with higher MgO content in the SM-S sinter. Dicalcium ferrite, mostly in an anhedral form, crystallized as the matrix phase and accumulated some $\mathrm{SiO}_{2}$ and $\mathrm{Al}_{2} \mathrm{O}_{3}$. For SFCA, which was the most widespread calcium ferrite type in the SM-S sinter, two compositional types were found. In the first, high $\mathrm{Fe}_{2} \mathrm{O}_{3}$ and $\mathrm{CaO}$ contents were typical, while other constituents were only minor. Both $\mathrm{Al}_{2} \mathrm{O}_{3}$ and $\mathrm{MgO}$ were below 1 wt \%. $\mathrm{No} \mathrm{SiO}_{2}$ was detected in most analyses. This SFCA appeared in a phase assemblage together with magnetite, dicalcium ferrite, and larnite in areas with a basicity of about 3.5 (Figure 13c). Similar to other ferrites, this type had prismatic morphology. The second SFCA type accumulated much more silica and alumina, $7.6 \mathrm{wt} \%$ and $3.8 \mathrm{wt} \%$ on average, respectively. It crystallized together with magnetite and glass and was the richest in $\mathrm{SiO}_{2}$. The basicity of these regions was significantly lower compared with the former including having values of about 1.5 (Figure 13d). In addition, mono-calcium ferrite crystals crystallized at points with local basicity of 6.3 (Figure 13e).

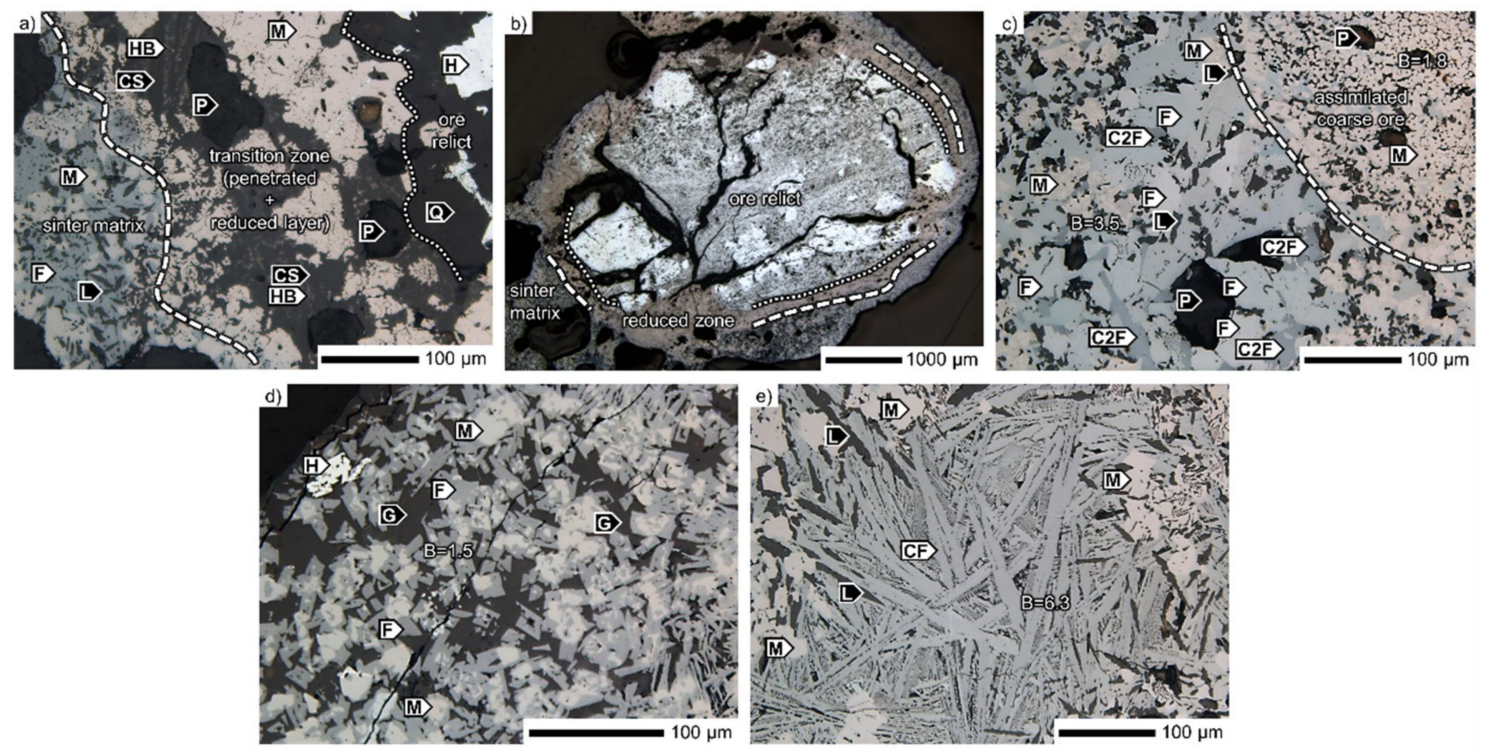

Figure 13. Reflected light micrographs of the SM-S sinter. B: $\mathrm{CaO} / \mathrm{SiO}_{2}, \mathrm{CF}$ : monocalcium ferrite, CS: pseudowollatonite, C2F: dicalcium ferrite, F: SFCA, G: glass, H: hematite, L: larnite, M: magnetite, P: pore, Q: quartz.

Table 8. Average chemical composition of the secondary phases in the SM-S sinter, wt \%.

\begin{tabular}{|c|c|c|c|c|c|c|c|c|}
\hline Phase & $\mathrm{Fe}_{2} \mathrm{O}_{3}$ & $\mathrm{CaO}$ & $\mathrm{SiO}_{2}$ & $\mathrm{Al}_{2} \mathrm{O}_{3}$ & $\mathrm{MgO}$ & $\mathrm{TiO}_{2}$ & $\mathrm{P}_{2} \mathrm{O}_{5}$ & $\mathrm{FeO}$ \\
\hline magnetite & 95.4 & 1.9 & 0.1 & 1.1 & 1.6 & - & - & - \\
\hline monocalcium ferrite & 72.8 & 26.4 & 0.0 & 0.7 & - & - & - & - \\
\hline dicalcium ferrite & 50.0 & 44.3 & 3.0 & 2.4 & - & 0.2 & - & - \\
\hline SFCA-I & 82.5 & 13.2 & 0.4 & 1.6 & 2.2 & - & - & - \\
\hline SFCA (a) & 79.3 & 19.5 & 0.0 & 0.4 & 0.7 & - & - & - \\
\hline SFCA (b) & 69.1 & 18.6 & 7.6 & 3.8 & 0.7 & - & - & - \\
\hline larnite & - & 65.6 & 30.2 & 0.0 & 0.0 & - & 0.1 & 4.0 \\
\hline iron-calcium olivine * & - & 40.4 & 34.1 & 5.4 & 1.3 & - & - & 18.7 \\
\hline Glass * & - & 45.8 & 35.7 & 3.3 & 0.5 & 0.2 & - & 14.6 \\
\hline
\end{tabular}


According to the phase analysis performed with XRD, SM-S consisted of hematite, magnetite, brownmillerite, larnite, and quartz (Figure 14). SFCA and SFCA-I could not be clearly identified, but, in this case, both phases were probably related to the unlabeled peaks with low intensity in the $2 \theta$-range from $30^{\circ}$ to $45^{\circ}$.

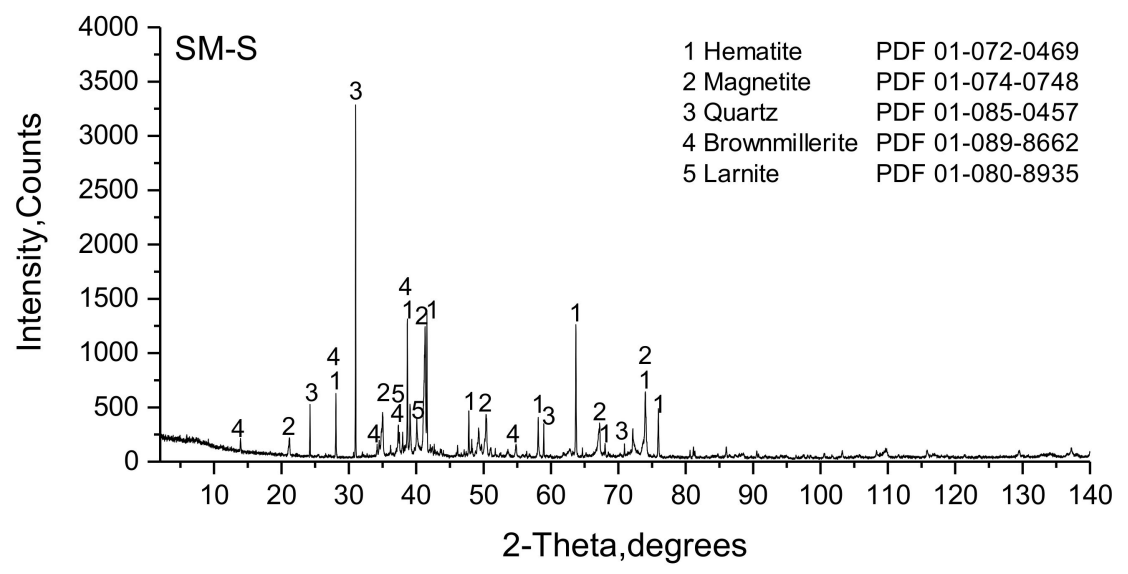

Figure 14. Powder diffractogram of the SM-S sinter.

\section{Discussion}

\subsection{Conditions for Primary Melt Formation and Ore Assimilation}

Considering the non-uniform distribution of chemical constituents within the ore size fractions, there were different conditions for phase formation during the sintering process. In line with this fact, granule structures typical for each mixture are illustrated in Figure 15. The composition of nuclei represents the overall composition of nucleus-sized particles in each mixture. Regarding the coke located in the adhering layer and the large interfacial area caused by fine particle size of both ore and limestone, the adhering layer is the place where the initial solid-state reactions and primary melting take place.

In fact, there are different suggestions in the literature regarding what particle size should be considered as the border between adhering and nuclei particles [33,34]. Nevertheless, the reactivity of the fines must also be taken into account. For purposes of this study, the particles of $-1 \mathrm{~mm}$ were considered the adhering fines for all of our sintering mixtures. The estimated chemical composition of the adhering layer of granules in each mixture is shown in Table 9. Furthermore, establishing useful basicity is of interest in order to predict the sinter reaction and melting characteristics, as mentioned in the work of Clout and Manuel [35]. The basicity of the sintering fines determined the useful basicity (Table 9), while the impact of the coarse ore particles is limited only to their surface part.
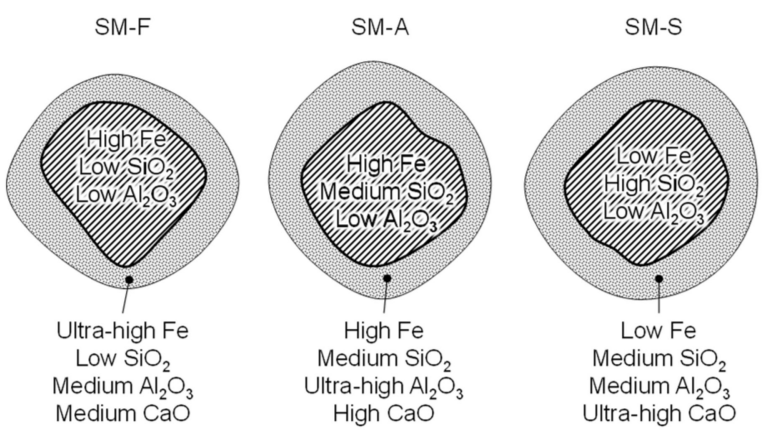

Figure 15. Granule structure within different mixtures. 
Table 9. Estimated chemical composition of the adhering layers, wt \%.

\begin{tabular}{cccccc}
\hline Mixture & $\mathbf{F e}_{\text {total }}$ & $\mathbf{C a O}$ & $\mathbf{S i O}_{\mathbf{2}}$ & $\mathbf{A l}_{\mathbf{2}} \mathbf{O}_{\mathbf{3}}$ & $\mathbf{C a O} / \mathrm{SiO}_{\mathbf{2}}$ \\
\hline SM-F & 57.6 & 9.7 & 2.7 & 1.6 & 3.6 \\
SM-A & 48.2 & 14.7 & 3.9 & 8.1 & 3.7 \\
SM-S & 39.8 & 29.8 & 6.3 & 2.0 & 4.7 \\
\hline
\end{tabular}

For better understanding of the primary reaction mechanisms, only the adhering fines were plotted into the $\mathrm{CaO}-\mathrm{Fe}_{2} \mathrm{O}_{3}-\mathrm{SiO}_{2}$ (CFS) phase diagram. Because the sintering process could be divided into two stages, according to the temperature and atmosphere, the CFS system in the reducing atmosphere $\mathrm{pO}_{2}=5 \times 10^{-3}$ atm (Figure 16a) represents the heating stage with reducing gases from the fuel combustion, and the CFS system in air (Figure 16b) the cooling stage with sucked fresh air. (The diagrams choose correspondence to the major chemical components of the adhering fines and the current described systems. Unfortunately, there is no CFS system in reducing the atmosphere with $\mathrm{Al} 2 \mathrm{O} 3$ participation in the current literature. Therefore, only CFS were used.) Primary melt formation paths will be discussed below, together with the specific ore assimilation behavior.

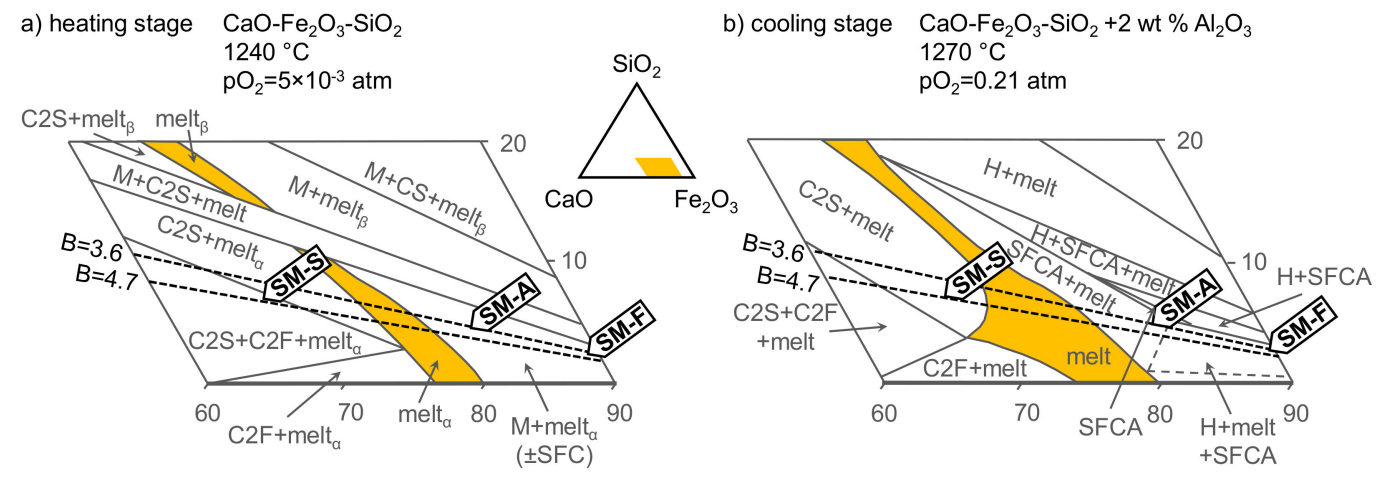

Figure 16. Adhering fines of SM-F, SM-A, and SM-S mixtures, according to chemical composition plotted into the $\mathrm{CaO}-\mathrm{Fe}_{2} \mathrm{O}_{3}-\mathrm{SiO}_{2}$ phase diagram's isothermal sections. Section (a) $\mathrm{CaO}-\mathrm{Fe}_{2} \mathrm{O}_{3}-\mathrm{SiO}_{2}$ system at $1240{ }^{\circ} \mathrm{C}$ and oxygen partial pressure $\mathrm{pO}_{2}=5 \times 10^{-3}$ atm. Section (b) $\mathrm{CaO}-\mathrm{Fe}_{2} \mathrm{O}_{3}-\mathrm{SiO}_{2}$ system with $2 \mathrm{wt} \% \mathrm{Al}_{2} \mathrm{O}_{3}$ at $1270{ }^{\circ} \mathrm{C}$ in air. Abbreviations denote: M: magnetite, $\mathrm{H}$ : hematite, SFC: silicoferrite of calcium (solid solution), $\mathrm{C} 2 \mathrm{~F}$ : dicalcium ferrite, $\mathrm{C} 2 \mathrm{~S}: \mathrm{Ca}_{2} \mathrm{SiO}_{4}, \mathrm{CS}: \mathrm{CaSiO}_{3}$. In the sections, dashed lines mark the useful basicity. Compositional range in wt \%. Diagrams adapted from Pownceby and Clout [36].

\subsubsection{Iron-Rich Ore Sinter}

As shown, the iron-rich mixture SM-F is located in the iron oxide stable region, which consists of hematite in the early stages. Hematite decomposes to magnetite at a temperature of $1457^{\circ} \mathrm{C}$ :

$$
6 \mathrm{Fe}_{2} \mathrm{O}_{3}=4 \mathrm{Fe}_{3} \mathrm{O}_{4}+\mathrm{O}_{2(\mathrm{~g})} \Delta H^{\circ}{ }_{298}=464.47 \mathrm{~kJ}
$$

Because this temperature was not reached in the sinter bed (peak temperature measured: $1289{ }^{\circ} \mathrm{C}$ ), the hematite-magnetite transformation was strongly promoted by using the reducing atmosphere during the fuel combustion:

$$
6 \mathrm{Fe}_{2} \mathrm{O}_{3}+2 \mathrm{CO}_{(\mathrm{g})}=4 \mathrm{Fe}_{3} \mathrm{O}_{4}+2 \mathrm{CO}_{2(\mathrm{~g})} \Delta H^{\circ} 298=-101.46 \mathrm{~kJ}
$$

However, during this process, the magnetite crystals remained in the solid state. Therefore, the primary melt formation was limited to reactions resulting in $\mathrm{CaO}-\mathrm{SiO}_{2}-\mathrm{Fe}_{2} \mathrm{O}_{3} / \mathrm{FeO}\left(-\mathrm{Al}_{2} \mathrm{O}_{3}\right)$ slag phase formation, which solidified as glass in the final microstructure. According to the diagram in Figure 16a, the melt phase should be rich in iron. Presence of SFC (SFCA) was limited in the reducing atmosphere. However, the glass that solidified in the final microstructure contained only $17 \mathrm{wt} \% \mathrm{FeO}$, which indicates precipitation of 
new magnetite (and SFCA) crystals during cooling (Figure 16b). The main bonding mechanism besides the intergranular glass was the magnetite recrystallization bond (grain to grain), for which a high bed temperature is necessary. This microstructure with high iron content more closely resembles the typical blast furnace pellet microstructure, where limited ferrite or silicate based bonding phases occur. Because of the inhomogeneity of the limestone distribution within the granules (despite careful laboratory mixing and homogenization), calcium ferrite-based melt formed as well. The $\mathrm{Al}_{2} \mathrm{O}_{3}$ distributed in the Carajás ore fines supported SFCA formation. The potential loss of fine-grained limestone particles during the granulation stage should be taken into account. For this reason, significantly lower useful basicity was observed.

The martite-goethite ore, playing a nucleus role within the granules, was always fully assimilated in the sinters. Depending on the adhering layer's chemical composition, migration of $\mathrm{Ca}^{2+}$ ions caused the formation of glass (rarely SFCA) in the bulk ore (Figure 17a). The original porosity of the Carajás ore as well as the goethite dehydration created a very porous ore body during sintering, which considerably promoted the primary melt penetration as well as $\mathrm{Fe}^{3+} \rightarrow \mathrm{Fe}^{2+}$ reduction by the gaseous reductant $[37,38]$. Consequently, almost the entire coarse ore volume was assimilated/reduced and the single remaining sign of the coarse ore presence was the typical clustered porosity (as presented in Figure $7 \mathrm{~b}$ ). In the case of dense martite-quartz ore, the insufficient volume of melt was not able to penetrate the nucleus ore particles and only wetted the ore surface. Due to coke combustion close to the nucleus surface, the layer of martite was reduced to magnetite and thermally affected quartz formed, as depicted in Figure 17b. As a consequence, the Zaporozhskiy coarse ore without secondary bonding phases weakened the sinter body. However, the low blending ratio of the Zaporozhskiy ore compensated for this negative impact.

a)

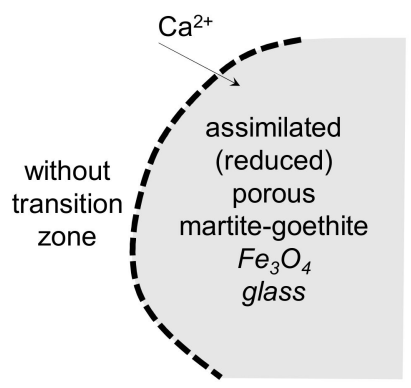

b)

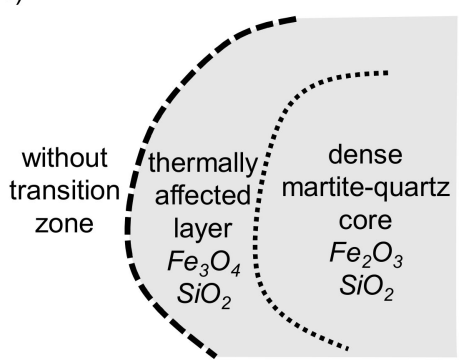

Figure 17. Ore assimilation scheme in the SM-F sinter.

\subsubsection{High-Alumina Iron Ore Sinter}

Although the starting composition of SM-A adhering fines could be plotted almost within the same "magnetite + melt" field of the $\mathrm{CaO}-\mathrm{Fe}_{2} \mathrm{O}_{3}-\mathrm{SiO}_{2}$ system as the SM-F sample (Figure 16a), the former high alumina content must be considered because it highly promotes the formation and stabilization of calcium ferrites [39]. The adhering fine composition of the SM-A mixture is very close to the starting composition of the mixture used for SFCA synthesis in the work of Webster et al. [40], where formation of dicalcium ferrite and subsequent monocalcium ferrite in the solid state initialized the sintering reactions:

$$
\begin{gathered}
2 \mathrm{CaO}+\mathrm{Fe}_{2} \mathrm{O}_{3}=\mathrm{Ca}_{2} \mathrm{Fe}_{2} \mathrm{O}_{5} \Delta H^{\circ}{ }_{298}=-40.22 \mathrm{~kJ} \\
2 \mathrm{CaO}+\frac{1}{2} \mathrm{Al}_{2} \mathrm{O}_{3}+\frac{1}{2} \mathrm{Fe}_{2} \mathrm{O}_{3}=\mathrm{Ca}_{2}\left(\mathrm{Fe}, \mathrm{Al}_{2}\right)_{2} \mathrm{O}_{5} \Delta H^{\circ}{ }_{298}=-28.87 \mathrm{~kJ} \\
\mathrm{Ca}_{2} \mathrm{Fe}_{2} \mathrm{O}_{5}+\mathrm{Fe}_{2} \mathrm{O}_{3}=2 \mathrm{CaFe}_{2} \mathrm{O}_{4} \Delta H^{\circ}{ }_{298}=-2.09 \mathrm{~kJ}
\end{gathered}
$$

As can be seen from the reaction heat of the dicalcium aluminoferrite formation (Equation (4)), the exothermic energy released during the reaction is lower than that in the pure dicalcium ferrite formation (Equation (3)). Therefore, a heat deficit occurred compared with the low-alumina sintering. Furthermore, increasing content of $\mathrm{Al}_{2} \mathrm{O}_{3}$ also increased the melting temperature of SFCA and, thus, 
the heat demand for primary melt formation [36]. At the same time, the high-alumina content in iron ore sinters is associated with high viscosity of the melt [41,42]. This is more significant than the $\mathrm{SiO}_{2}$ influence because of the calcium ferrite-based melt formation process. While $\mathrm{Al}_{2} \mathrm{O}_{3}$ enters the calcium ferrite reactions from the start, $\mathrm{SiO}_{2}$ remains inert for a certain period and then dissolves slowly [40]. Furthermore, higher $\mathrm{Al}_{2} \mathrm{O}_{3}$ concentration and finer size distribution in comparison with $\mathrm{SiO}_{2}$ particles favored the alumina solution. Due to the high coke content in the SM-A mixture, elevated temperatures (peak: $1420^{\circ} \mathrm{C}$ ) were reached during sintering. In addition, wide combustion and sintering zones provided sufficient conditions for melting and longer dwell times of the materials at the highest temperatures. Compared with SM-F and SM-S, the reaction time above $1100{ }^{\circ} \mathrm{C}$ for SM-A was approximately 1.7 and 2.4 times longer, respectively. Upon cooling, the SM-A adhering fines belonged in the part that was compositionally almost ideal for the stable SFCA in the final microstructure (Figure 16b). However, in the sinter samples, the reduction degree was too high. Stable magnetite and wüstite prevented larger SFCA formation.

The assimilation of the martite-goethite ore proceeded in a very similar way to the previously discussed SM-F sinter. The difference was in the penetrating melt, which was of higher basicity, and, thus, large volumes of SFCA crystallized between the magnetite crystals in the ore bulk. Again, the elevated natural porosity and porosity triggered by goethite decomposition enabled advanced assimilation of the Carajás ore (Figure 18a). In the banded martite-microplaty hematite core, the intercrystalline pore space enabled both reduction and melt penetration. However, this was not as intense as in the martite-goethite ore. In this case, unassimilated but thermally affected hematite cores were surrounded by two large transition layers, reduced to magnetite, and penetrated by melt. However, the migration of $\mathrm{Al}^{3+}$ was mostly limited due to the increased melt viscosity, because of the situation presented in Figure 9b. A larger area with higher participation of $\mathrm{Al}_{2} \mathrm{O}_{3}, \mathrm{SiO}_{2}$, and $\mathrm{CaO}$, all together with the iron oxides, was analyzed (the overall local composition was $64.2 \mathrm{wt} \% \mathrm{Fe}_{2} \mathrm{O}_{3}+$ $\mathrm{FeO}, 16.4 \mathrm{wt} \% \mathrm{CaO}, 11.6 \mathrm{wt} \% \mathrm{SiO}_{2}$, and $7.9 \mathrm{wt} \% \mathrm{Al}_{2} \mathrm{O}_{3}$ ). Admittedly, there could be an alumina source at the coarse ore nucleus edge, but the $\mathrm{Al}^{3+}$ cations were propagated over a larger area into the nucleus, as well as the surrounding sinter matrix. The viscosity of the melt within the $\mathrm{Al}_{2} \mathrm{O}_{3}-\mathrm{CaO}-\mathrm{SiO}_{2}$ system increases in line with the silica content, but accompanying $\mathrm{Fe}_{x} \mathrm{O}$ (a result of the reducing atmosphere) significantly decreases the penetrating melt viscosity, which is a possible explanation for the easier propagation of $\mathrm{Al}^{3+}$ under the previously mentioned conditions [43]. This case is illustrated in Figure 18b.

a)

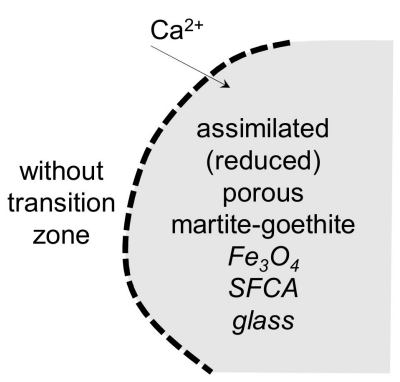

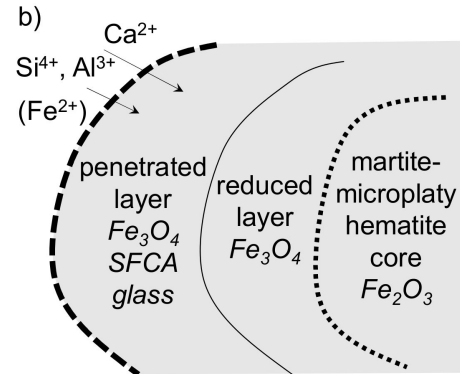

Figure 18. Ore assimilation scheme in SM-A sinter.

\subsubsection{High-Silica Iron Ore Sinter}

In Figure 16a, the SM-S adhering fines are situated at the boundary where larnite and dicalcium ferrite are the stable phases. Prior to the associated reactions, decomposition of a large amount of limestone took place:

$$
\mathrm{CaCO}_{3}=\mathrm{CaO}+\mathrm{CO}_{2(\mathrm{~g})} \Delta H^{\circ}{ }_{298}=178.75 \mathrm{~kJ}
$$

This was particularly true for the SM-S sintering. The heat demand for this reaction is clear from the temperatures reached during the sintering of this mixture, which were the lowest from all 
sintered compositions. The formation of larnite is also more favorable in energy terms compared with dicalcium ferrite formation (Equation (3)):

$$
2 \mathrm{CaO}+\mathrm{SiO}_{2(\text { fines })}=\mathrm{Ca}_{2} \mathrm{SiO}_{4} \Delta H^{\circ}{ }_{298}=-125.28 \mathrm{~kJ}
$$

Various calcium ferrites and dicalcium silicate crystals dominated the final microstructure of the SM-S sinter. Again, besides silicates, $\mathrm{Al}_{2} \mathrm{O}_{3}$ in the mixture supported the formation of calcium ferrites. Some researchers have suggested that the formation of silicoferrite of calcium and SFCA is a result of the larnite, hematite, and monocalcium ferrite reaction [44,45]. As shown in the FCS diagram in air (Figure 16b), besides larnite, no other phase was stable at $1270{ }^{\circ} \mathrm{C}$ in the solid state, which indicates that all other phases precipitated out from the melt. Although the measured bed temperature reached only $1190^{\circ} \mathrm{C}$, the eutectics near the projected SM-S fines composition allowed melting at around this temperature. During cooling, crystallization of the eutectic compounds dicalcium ferrite, dicalcium silicate, and SFCA occurred. The position of the SM-S fine mixture in the diagram in Figure 16b, far from the ideal SFCA composition, could be an indication regarding why specific high-Ca low-Si-Al SFCA dominated the microstructure instead of an SFCA with ordinary composition.

The assimilation of the Sukha Balka ore was characterized by the simultaneous presence of dense martite and coarse quartz grains:

1. The behavior of coarse quartz depended on the composition of the adhering fines:

- At low useful basicity, the adhering fines did not generate sufficient primary melt to penetrate into the quartz core. The thermal impact on the original quartz mass with microvoids between the crystals did not increase the porosity but homogenized the quartz crystals into a dense mass without pores, which did not allow any penetration of the primary melt. The transition zone was, therefore, missing.

- Primary melts with higher basicity penetrated into the quartz or martite surface by forming a thin transition layer. Depending on the useful basicity, two phase assemblages formed (Figure 19a):

$$
\mathrm{Ca}_{2} \mathrm{Fe}_{2} \mathrm{O}_{5}+2 \mathrm{SiO}_{2(\text { coarse })}+\mathrm{CO}_{(\mathrm{g})}=(\mathrm{Ca}, \mathrm{Fe})^{2+}{ }_{2} \mathrm{SiO}_{4}+\mathrm{CaFe}^{2+} \mathrm{SiO}_{4}+\mathrm{CO}_{2(\mathrm{~g})}, \Delta H^{\circ}{ }_{298}=-142.47 \mathrm{~kJ}
$$

or

$$
2 \mathrm{CaFe}_{2} \mathrm{O}_{4}+3 \mathrm{SiO}_{2(\text { coarse })}+2 \mathrm{CO}_{(\mathrm{g})}=\mathrm{CaSiO}_{3}+\mathrm{CaFe}^{2+} \mathrm{Si}_{2} \mathrm{O}_{6}+3 \mathrm{FeO}+2 \mathrm{CO}_{2(\mathrm{~g})}, \Delta H^{\circ} 298=-150.09 \mathrm{~kJ}
$$

where the free $\mathrm{FeO}$ formed an additional secondary magnetite. Equation (8) involves phases with idealized stoichiometry. Due to lack of thermodynamic data, kirschsteinite was used instead of iron-calcium olivine for the heat reaction calculation. Equation (9) is in agreement with the formation of phases in penetrated areas observed in other studies [46,47]. In both cases, melt penetration was exothermic in character due to the formation of (iron-)calcium silicates.

2. When the primary melt penetrated the martite core, SFCA formed on the boundary (Figure 19b). In Section 3.4, larger transition layers and coarse, fully reacted siliceous cores were observed, e.g., in Figure 12b. On the one hand, smaller particles show higher assimilation rates, but, on the other hand, because of different sectioning of the samples, only the surface of the coarse ore particles could be shown on the micrograph, which is likely the case here. 

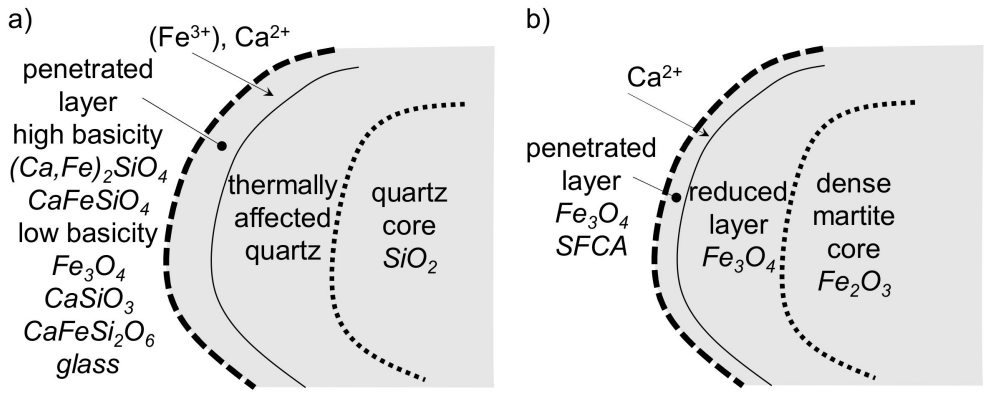

Figure 19. Ore assimilation scheme in the SM-S sinter.

\subsection{Secondary Phases}

The secondary phases, which formed due to reactions in the solid state or by crystallization from the melt, are solid solutions rather than chemical compounds with a fixed chemical composition. The latter were almost only hematite and monocalcium ferrite, which appeared rarely in the sinters, including the first as re-oxidized magnetite and the second only in the SM-S sinter.

The compositions of the other phases reflected the specific chemical conditions in the three different sinters. Magnetite, as a typical phase hosting impurity, was purest in the SM-F sinter, which is in line with the expectations. In the SM-A and SM-S sinters, the ability to dissolve $\mathrm{Al}^{3+}$ and $\mathrm{Ca}^{2+}+\mathrm{Mg}^{2+}$ cations, respectively, was confirmed.

The crystalline phase with the most variable chemical composition was the SFCA. However, the alumina-richest SFCA was found in the SM-F sinter because of the higher local alumina accumulation from the Carajás ore. While the SFCA in the SM-A sinter was lower in $\mathrm{Al}_{2} \mathrm{O}_{3}$, it was more represented in the sinter matrix than in the SM-F. One of the reasons for this was the more even distribution of alumina in the sinter matrix. Despite the highest overall silica content adjusted in the SM-S sinter, the one SFCA type was a little poorer in $\mathrm{SiO}_{2}$ than the SFCA crystals in the SM-A sinter.

As presented and discussed earlier, the chemical composition of ore fines, including the useful basicity, created conditions for the formation of phases quite different from the expected compositions. The calcium ferrites in the SM-S sinter were a special case. The main bonding phase was calcium ferrite with less than $1 \mathrm{wt} \% \mathrm{Al}_{2} \mathrm{O}_{3}$ and $\mathrm{MgO}$ and almost no $\mathrm{SiO}_{2}$. The average content of $\mathrm{CaO}(\sim 19.5 \mathrm{wt} \%)$ was higher compared to the usual SFCA ( 16-17 wt \%), but lower than the theoretical CaO content of monocalcium ferrite $\mathrm{CaFe}_{2} \mathrm{O}_{4}(28.1 \mathrm{wt} \%)$. In addition, mono-calcium ferrite was present in the SM-S sinter, which allowed easy distinction of both ferrites. The $\mathrm{CaO}$ content in calcium differrite $\mathrm{CaFe}_{4} \mathrm{O}_{7}$ is only $16.4 \mathrm{wt} \%$. Therefore, this phase would also seem to be implausible. At first sight, the presence of the unusual ferrite type with almost no impurity cations did not correspond with the complex calcium ferrites. However, after recalculation of the chemical composition determined from EDS analysis using the SFCA-compatible formula $\left(\mathrm{X}_{2} \mathrm{Y}_{6} \mathrm{Z}_{6} \mathrm{O}_{20} \rightarrow \mathrm{Ca}_{2}(\mathrm{Ca}, \mathrm{Fe})_{6} \mathrm{Fe}_{6} \mathrm{O}_{20}\right)$, the discussed CaO content nearly reached the real EDS values. SFCA with this composition was also identified in the work of Zhang et al. [48]. However, in order to adequately answer the question of this unusual calcium ferrite type, more detailed research is necessary.

The detection of SFCA as well as SFCA-I and precise quantification of the present phases through application of XRD remains difficult. With the variable chemical composition of SFCA and SFCA-I affecting the lattice parameters of the phases, the related peak positions differ. Thus, the defined peak maxima belonging to specific $(h k l)$ values do not occur. A Le-Bail fit with lattice parameters of SFCA described by Liles et al. [11] was performed on the SM-S mixture (Figure 20). As a result, correlation between numerous peaks in the range of $35^{\circ}-75^{\circ} 2 \theta$ and the used unit cell was deduced. Moreover, superposition of the peaks belonging to other phases present in the sinter was verified. Distinct peak positions for SFCA existed in the $2 \theta$ range of $10^{\circ}-15^{\circ}$, which were confirmed by Liles et al. [11] in single-phase SFCA. In the diffractogram of SM-S, however, the intensity of the peaks concerned was insufficient. The peaks associated with mono-calcium ferrite, which could be helpful for identifying SFCA with unusual composition that were not detected. 


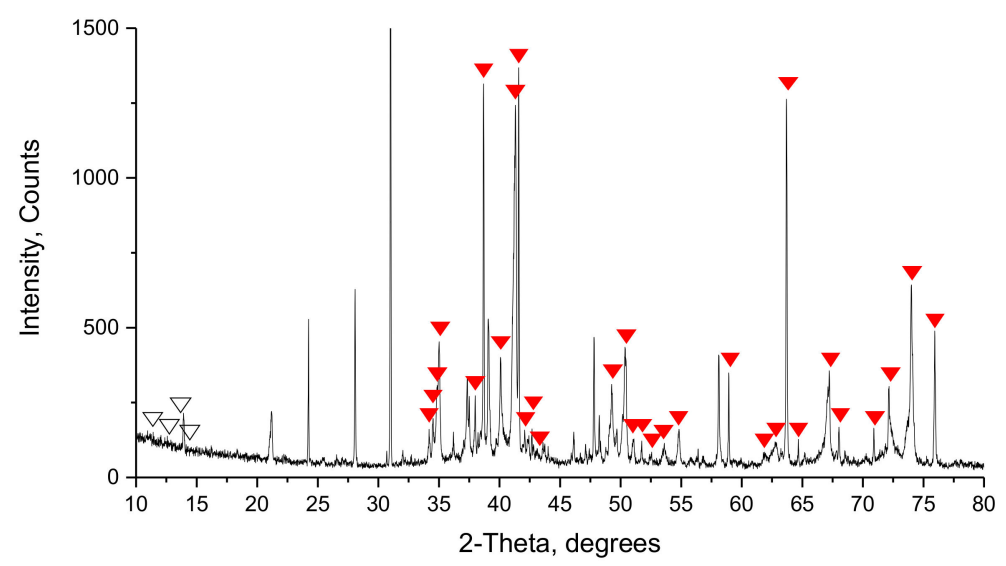

Figure 20. Detailed view on the powder diffractogram of the SM-S sinter. The solid red triangles mark the positions of SFCA covered under diffraction patterns of other phases and the blank triangles mark the positions of SFCA, where SFCA patterns are missing in the sample.

The impurity-bearing phases (mostly hydrates) identified in the raw ores were probably easily dissolved by the secondary phases due to the cracks produced by dehydration. Additionally, the total amount of minor components such as $\mathrm{TiO}_{2}$ or $\mathrm{P}_{2} \mathrm{O}_{5}$ was too low to form unique phases.

\subsection{Some Implications for the Commercial Sintering}

The use of fine-grained limestone highly promotes its assimilation since no coarser white grains remained in the final sinter microstructure, as either original limestone or calcined lime. These are the points, which weaken the sinter because of insufficient strength and/or by sinter cracking caused by hydration and a subsequent volume increase. The disadvantage of fine limestone blending is the material loss during the granulation stage.

The gangue distribution within the granulometric fractions of ores determines the active reaction system during sintering. Identification of the gangue particle size within ores helps in understanding the key sintering reactions and enables better control of the sintering mechanism.

The coarse quartz particles from high silica ores appear as unassimilated coarse grains in the final sinter. The overall sinter basicity, therefore, does not describe the active reaction system by forming melt and secondary phases. For this, the value of useful basicity is needed. The high- $\mathrm{SiO}_{2}$ sinter matrix consists of iron oxide-calcium ferrites-calcium silicate phase assemblage, which bonds the coarse nucleus ores well.

By blending coarser limestone or dolomite, the useful basicity decreases and more iron-calcium silicates form in the matrix, as presented in the earlier study [47].

Alumina gangue blended in fine form (in sinter plants as a part of the fine ore) is highly reactive and promotes the formation of SFCA. The positive effect of the large surface area is similar to the dehydrated gibbsite. Using porous iron ores with goethite, the admixture facilitates primary melt penetration and causes advanced ore assimilation. However, the high coke breeze consumption is a significant disadvantage.

\section{Conclusions}

The ore assimilation and secondary mineral phases in iron-rich, high-alumina, and high-silica iron ore sinters were investigated with special attention paid to the conditions determined by the component distribution within the adhering fines and coarse ore particles. The conclusions are summarized below.

The chemical composition of iron ore across the size fractions significantly differs and has a large influence on the reaction system, which is practically defined by the chemical composition of adhering fines (including ore, fluxes, and fuel) acting as the adhering layer within the green granule. 
The rich iron ore accompanying very low gangue content does not allow widespread primary melt formation. Iron oxide crystals bonded with the recrystallization bond or the intergranular glass with less SFCA dominate the final sinter matrix. Use of goethite-containing ores with additional natural porosity enables increased assimilation of the coarser ore particles and successfully eliminates the negative impact of a low primary melt volume.

High-alumina iron ores support the formation of calcium ferrites. However, high content of $\mathrm{Al}_{2} \mathrm{O}_{3}$ in the reactive fines and subsequently formed SFCA increases the melting temperature and the viscosity of the primary melt. In spite of this, sufficient primary melt formation and advanced coarse ore assimilation occurred due to higher coke addition. The goethitic and porous nature of coarse ores is also significant since they both improve the penetration of the primary melt. The main $\mathrm{Al}_{2} \mathrm{O}_{3}$-collecting phase is the SFCA, but the $\mathrm{Al}_{2} \mathrm{O}_{3}$ content locally differs. Additionally, an aluminous gehlenite phase forms in the sinter.

In the sintering of high-silica iron ores, the large amount of fluxing limestone consumes much of the heat from the fuel combustion. However, excessive primary melt forms due to the low-melting eutectic phases. The ultra-high useful basicity in high-silica sinter promotes the magnetite-calcium ferrites-calcium silicates sinter matrix. Because of the accumulation of $\mathrm{SiO}_{2}$ in the silicates, more calcium ferrite types appear. Besides dicalcium ferrite, the SFCA phases are the most widespread form in several compositional varieties including the ordinary high-Si and an Si-free variety. The coarse quartz particles remain almost unassimilated, but are well bonded with the sinter matrix.

Author Contributions: Conceptualization, R.M. Investigation, R.M. and V.S.G. Methodology, R.M. and R.F. Resources, M.F. Supervision, M.F. and R.F. Writing—original draft, R.M. Writing—review and editing, V.S.G.

Funding: Slovak Research and Development Agency, grant number APVV-16-0513, funded this research.

Acknowledgments: R.M. highly appreciates the kind assistance of Jaroslav Briančin (SAS Košice) by SEM. The authors thank Jaroslav Legemza (TU Košice) for XRF of iron ores. A valuable discussion and revision of the manuscript by Volker Kahlenberg (University of Innsbruck) is also acknowledged.

Conflicts of Interest: The authors declare no conflicts of interest.

\section{References}

1. Zhang, J.L.; Hu, Z.W.; Zuo, H.B.; Liu, Z.J.; Zhao, Z.X.; Yang, T.J. Ore blending ratio optimisation for sintering based on iron ore properties and cost. Ironmak. Steelmak. 2014, 41, 279-285. [CrossRef]

2. Li, T.; Sun, C.; Liu, X.; Song, S.; Wang, Q. The effects of $\mathrm{MgO}$ and $\mathrm{Al}_{2} \mathrm{O}_{3}$ behaviours on softening-melting properties of high basicity sinter. Ironmak. Steelmak. 2018, 45, 755-763. [CrossRef]

3. Padula, V.P.; Pereira, C.A.; Vieira, C.B.; Pimenta, H.P.; Vieira, M.B. Efeitos das características granulométricas e mineralógicas da sílica contida no itabirito compacto adicionada em um sinter feed hematítico para sinterização. Rem Revista Escola de Minas 2011, 64, 347-352. [CrossRef]

4. Silva, M.S.S.; Lima, M.M.F.; Graça, L.M.; Lima, R.M.F. Bench-scale calcination and sintering of a goethite iron ore sample. Int. J. Miner. Process. 2016, 150, 54-64. [CrossRef]

5. Magalhaes, M.S.; Brandao, P.R.G.; Tavares, R.P. Types of goethite from Quadrilátero Ferrífero's iron ores and their implications in the sintering process. Miner. Process. Extr. Metall. 2007, 116, 54-64. [CrossRef]

6. Mežibrický, R.; Fröhlichová, M.; Legemza, J. High-SiO 2 iron ore sintering: Central \& Eastern Europe scenario. Metalurgija 2019, 58, 161-164.

7. Umadevi, T.; Mahapatra, P.C.; Prabhu, M. Influence of $\mathrm{MgO}$ addition on microstructure and properties of low and high silica iron ore sinter. Miner. Process. Extr. Metall. 2013, 122, 238-248. [CrossRef]

8. Zhou, M.; Jiang, T.; Yang, S.; Xue, X. Sintering behaviors and consolidation mechanism of high-chromium vanadium and titanium magnetite fines. Int. J. Miner. Metall. Mater. 2015, 22, 917-925. [CrossRef]

9. Chen, S.; Fu, X.; Chu, M.; Liu, Z.; Tang, J. Life cycle assessment of the comprehensive utilisation of vanadium titano-magnetite. J. Clean. Prod. 2015, 101, 122-128. [CrossRef]

10. Cai, B.; Watanabe, T.; Kamijo, C.; Susa, M.; Hayashi, M. Comparison between Reducibilities of Columnar Silico-ferrite of Calcium and Aluminum (SFCA) Covered with Slag and Acicular SFCA with Fine Pores. ISIJ Int. 2018, 58, 642-651. [CrossRef] 
11. Liles, D.C.; de Villiers, J.P.; Kahlenberg, V. Refinement of iron ore sinter phases: A silico-ferrite of calcium and aluminium (SFCA) and an Al-free SFC, and the effect on phase quantification by X-ray diffraction. Miner. Petrol. 2016, 110, 141-147. [CrossRef]

12. Webster, N.A.S.; Pownceby, M.I.; Pattel, R. Fundamentals of silico-ferrite of calcium and aluminium (SFCA) and SFCA-I iron ore sinter bonding phase formation: Effects of mill scale addition. Powder Diffract. 2017, 32, S85-S89. [CrossRef]

13. Takayama, T.; Murao, R.; Kimura, M. Quantitative Analysis of Mineral Phases in Iron-ore Sinter by the Rietveld Method of X-ray Diffraction Patterns. ISIJ Int. 2018, 58, 1069-1078. [CrossRef]

14. Ding, X.; Guo, X.M. The Formation Process of Silico-Ferrite of Calcium (SFC) from Binary Calcium Ferrite. Metall. Mater. Trans. B 2014, 45, 1221-1231. [CrossRef]

15. Sugiyama, K.; Monkawa, A.; Sugiyama, T. Crystal Structure of the SFCAM Phase $\mathrm{Ca}_{2}(\mathrm{Ca}, \mathrm{Mg}, \mathrm{Fe}, \mathrm{Al})_{6}(\mathrm{Fe}, \mathrm{Al}, \mathrm{Si})_{6} \mathrm{O}_{20}$. ISIJ Int. 2005, 45, 560-568. [CrossRef]

16. Mumme, W. The crystal structure of SFCA-II, $\mathrm{Ca}_{5.1} \mathrm{Al}_{9.3} \mathrm{Fe}^{3+}{ }_{18.7} \mathrm{Fe}_{2}+{ }_{0.9} \mathrm{O}_{48}$ a new homologue of the aenigmatite structure-type, and structure refinement of SFCA-type, $\mathrm{Ca}_{2} \mathrm{Al}_{5} \mathrm{Fe}_{7} \mathrm{O}_{20}$. Implications for the nature of the "ternary-phase solid-solution" previously reported in the $\mathrm{CaO}-\mathrm{Al}_{2} \mathrm{O}_{3}$-iron oxide system. Neues Jahrb. Miner. Abh. 2003, 178, 307-335.

17. Zöll, K.; Manninger, T.; Kahlenberg, V.; Krüger, H.; Tropper, P. Investigations on the crystal structure and the stability field of FCAM-I $\left(\mathrm{Ca}_{3} \mathrm{MgAl}_{6} \mathrm{Fe}_{10} \mathrm{O}_{28}\right)$, an iso-structure to SFCA-I. Metall. Mater. Trans. $B$ 2017, 48, 2207-2221. [CrossRef]

18. Zöll, K.; Kahlenberg, V.; Krüger, H.; Tropper, P. Investigations on FCAM-III ( $\left.\mathrm{Ca}_{2.38} \mathrm{Mg}_{2.09} \mathrm{Fe}^{3+}{ }_{10.61} \mathrm{Fe}^{2+}{ }_{1.59} \mathrm{Al}_{9.33} \mathrm{O}_{36}\right)$ : A new homologue of the aenigmatite structure-type in the system $\mathrm{CaO}-\mathrm{MgO}-\mathrm{Fe}_{2} \mathrm{O}_{3}-\mathrm{Al}_{2} \mathrm{O}_{3}$. J. Solid State Chem. 2018, 258, 307-319. [CrossRef]

19. Da Costa, E.; Coheur, J.P.; Vanderheyden, B.; Munnix, R. Slag formation in the adhering layer of granules and its reaction with nuclei in iron ore sintering. ISIJ Int. 1995, 35, 138-147. [CrossRef]

20. Wu, S.L.; Su, B.; Qi, Y.H.; Kou, M.Y.; Li, Y.; Zhang, W.L. Melt absorbability of iron ore nuclei and its influence on suitable liquid content of sintered body. Metall. Mater. Trans. B 2017, 48, 2469-2480. [CrossRef]

21. Nakashima, K.; Saito, N.; Shinozaki, S.; Tanaka, R.; Maeda, T.; Shimizu, M.; Mori, K. Wetting and penetration behavior of calcium ferrite melts to sintered hematite. ISIJ Int. 2004, 44, 2052-2056. [CrossRef]

22. Jeon, J.W.; Kim, S.W.; Suh, I.K.; Jung, S.M. Assimilation behavior of quasi-particle comprising high alumina pisolitic ore. ISIJ Int. 2014, 54, 2713-2720. [CrossRef]

23. Okazaki, J.; Higuchi, K.; Hosotani, Y.; Shinagawa, K. Influence of iron ore characteristics on penetrating behavior of melt into ore layer. ISIJ Int. 2003, 43, 1384-1392. [CrossRef]

24. Yoshimura, S.; Kurosawa, K.; Gonda, Y.; Sukenaga, S.; Saito, N.; Nakashima, K. Penetration behavior of calcium ferrite melts into hematite substrate. ISIJ Int. 2009, 49, 687-692. [CrossRef]

25. Umadevi, T.; Deodar, A.V.; Mahapatra, P.C.; Prabhu, M.; Ranjan, M. Influence of alumina on iron ore sinter properties and productivity in the conventional and selective granulation sintering process. Steel Res. Int. 2009, 80, 686-692.

26. Sinha, M.; Nistala, S.H.; Chandra, S.; Mankhand, T.R. Mineralogy of iron ores of different alumina levels from Singhbhum Belt and their implication on sintering process. J. Miner. Mater. Charact. Eng. 2015, 3, 180-193. [CrossRef]

27. Umadevi, T.; Sah, R.; Mahapatra, P.C. Influence of sinter basicity $\left(\mathrm{CaO} / \mathrm{SiO}_{2}\right)$ on low and high alumina iron ore sinter quality. Miner. Process. Extr. Metall. 2014, 123, 75-85. [CrossRef]

28. Bruker-AXS. DIFFRACplus Evaluation Package, version 4.2.1; Bruker: Billerica, MA, USA, 2016.

29. ICDD. PDF-4+ 2018; International Centre for Diffraction Data: Newtown Square, PA, USA, 2017.

30. Bruker-AXS; TOPAS. General Profile and Structure Analysis Software for Powder Diffraction Data, version 4.2; Bruker: Billerica, MA, USA, 2009.

31. Thompson, P.; Cox, D.E.; Hastings, J.B. Rietveld refinement of Debye-Scherrer synchrotron X-ray data from $\mathrm{Al}_{2} \mathrm{O}_{3}$. J. Appl. Crystallogr. 1987, 20, 79-83. [CrossRef]

32. Mežibrický, R.; Fröhlichová, M. Silico-ferrite of calcium and aluminum characterization by crystal morphology in iron ore sinter microstructure. ISIJ Int. 2016, 56, 1111-1113. [CrossRef]

33. Tobu, Y.; Nakano, M.; Nakagawa, T.; Nagasaka, T. Effect of granule structure on the combustion behavior of coke breeze for iron ore sintering. ISIJ Int. 2013, 53, 1594-1598. [CrossRef] 
34. Wu, S.L.; Zhu, J.; Bei, J.C.; Zhang, G.L.; Zhai, X.B. Effects of particle characteristics on the granulation ability of iron ores during the sintering process. Int. J. Miner. Metall. Mater. 2015, 22, 907-916. [CrossRef]

35. Clout, J.M.F.; Manuel, J.R. Fundamental investigations of differences in bonding mechanisms in iron ore sinter formed from magnetite concentrates and hematite ores. Powder Technol. 2003, 130, 393-399. [CrossRef]

36. Pownceby, M.I.; Clout, J.M.F. Importance of fine ore chemical composition and high temperature phase relations: Applications to iron ore sintering and pelletising. Miner. Process. Extr. Metall. 2003, 112, 44-51. [CrossRef]

37. Ware, N.; Manuel, J.R. Fundamental nucleus assimilation behaviour of haematite and goethite containing ores in iron ore sintering. Miner. Process. Extr. Metall. 2016, 125, 149-155. [CrossRef]

38. Donskoi, E.; Poliakov, A.; Holmes, R.; Suthers, S.; Ware, N.; Manuel, J.; Clout, J. Iron ore textural information is the key for prediction of downstream process performance. Miner. Eng. 2016, 86, 10-23. [CrossRef]

39. Scarlett, N.V.; Madsen, I.C.; Pownceby, M.I.; Christensen, A.N. In situ X-ray diffraction analysis of iron ore sinter phases. J. Appl. Cryst. 2004, 37, 362-368. [CrossRef]

40. Webster, N.A.S.; Pownceby, M.I.; Madsen, I.C.; Studer, A.J.; Manuel, J.R.; Kimpton, J.A. Fundamentals of Silico-Ferrite of Calcium and Aluminum (SFCA) and SFCA-I Iron Ore Sinter Bonding Phase Formation: Effects of $\mathrm{CaO}: \mathrm{SiO}_{2}$ Ratio. Metall. Mater. Trans. B 2014, 45, 2097-2105. [CrossRef]

41. Saito, N.; Hori, N.; Nakashima, K.; Mori, K. Viscosity of blast furnace type slags. Metall. Mater. Trans. B 2003, 34, 509-516. [CrossRef]

42. Sukenaga, S.; Gonda, Y.; Yoshimura, S.; Saito, N.; Nakashima, K. Viscosity measurement of calcium ferrite based slags during structural relaxation process. ISIJ Int. 2010, 50, 195-199. [CrossRef]

43. Allibert, M. Verein Deutscher Eisenhüttenleute. Slag Atlas, 2nd ed.; Verlag Stahleisen: Düsseldorf, Germany, 1995; pp. 379-380.

44. Ding, X.; Guo, X.M. Study of $\mathrm{SiO}_{2}$ involved in the formation process of silico-ferrite of calcium (SFC) by solid-state reactions. Int. J. Miner. Process. 2016, 149, 69-77. [CrossRef]

45. Wang, S.; Gao, W.; Kong, L. Formation mechanism of silicoferrite of calcium and aluminium in sintering process. Ironmak. Steelmak. 1998, 25, 296-301.

46. Yang, M.; Lv, X.; Wei, R.; Xu, J.; Bai, C. Wetting behavior of calcium ferrite slags on cristobalite substrates. Metall. Mater. Trans. B 2018, 49, 1331-1345. [CrossRef]

47. Mežibrický, R.; Fröhlichová, M. Mineral phases in iron ore sinters produced with oak sawdust substitute fuel. J. Min. Metall. B Metall. 2018, 54, 9-20. [CrossRef]

48. Zhang, G.; Wu, S.; Chen, S.; Su, B.; Que, Z.; Hou, C. Influence of gangue existing states in iron ores on the formation and flow of liquid phase during sintering. Int. J. Miner. Metall. Mater. 2014, 21, 962-968. [CrossRef]

(C) 2019 by the authors. Licensee MDPI, Basel, Switzerland. This article is an open access article distributed under the terms and conditions of the Creative Commons Attribution (CC BY) license (http://creativecommons.org/licenses/by/4.0/). 